\title{
Treatment Strategy for Multiple Myeloma to Improve Immunological Environment and Maintain MRD Negativity
}

\author{
Kazuhito Suzuki ${ }^{1,2}, *\left(\mathbb{D}\right.$, Kaichi Nishiwaki ${ }^{1,2}$ and Shingo Yano ${ }^{2}$ \\ 1 Department of Internal Medicine, Division of Clinical Oncology and Hematology, The Jikei University \\ Kashiwa Hospital, Tokyo 277-8567, Japan; nishiwaki@jikei.ac.jp \\ 2 Department of Internal Medicine, Division of Clinical Oncology and Hematology, The Jikei University School \\ of Medicine, Tokyo 105-8461, Japan; yano@jikei.ac.jp \\ * Correspondence: kaz-suzuki@jikei.ac.jp
}

check for updates

Citation: Suzuki, K.; Nishiwaki, K.; Yano, S. Treatment Strategy for Multiple Myeloma to Improve Immunological Environment and Maintain MRD Negativity. Cancers 2021, 13, 4867. https://doi.org/ 10.3390/cancers13194867

Academic Editor: Jo Caers

Received: 11 August 2021

Accepted: 24 September 2021

Published: 28 September 2021

Publisher's Note: MDPI stays neutral with regard to jurisdictional claims in published maps and institutional affiliations.

Copyright: (c) 2021 by the authors. Licensee MDPI, Basel, Switzerland. This article is an open access article distributed under the terms and conditions of the Creative Commons Attribution (CC BY) license (https:/ / creativecommons.org/licenses/by/ $4.0 /)$.
Simple Summary: Improving the immunological environment and eradicating minimal residual disease (MRD) are the two main treatment goals for long-term survival in patients with multiple myeloma (MM). An improved immunological environment may be useful for maintaining MRD negativity. Whether the ongoing treatment should be continued or changed if the MRD status remains positive is controversial. In this case, genetic, immunophenotypic, and clinical analysis of residual myeloma cells may be necessary to select the effective treatment for the residual myeloma cells. The purpose of this review is to discuss the MM treatment strategy to "cure MM" based on currently available therapies and expected immunotherapies via improvement of the immunological environment and maintenance of MRD negativity.

Abstract: Improving the immunological environment and eradicating minimal residual disease (MRD) are the two main treatment goals for long-term survival in patients with multiple myeloma (MM). Immunomodulatory drugs (IMiDs), monoclonal antibody drugs (MoAbs), and autologous grafts for autologous stem cell transplantation (ASCT) can improve the immunological microenvironment. ASCT, MoAbs, and proteasome inhibitors (PIs) may be important for the achievement of MRD negativity. An improved immunological environment may be useful for maintaining MRD negativity, although the specific treatment for persistent MRD negativity is unknown. However, whether the ongoing treatment should be continued or changed if the MRD status remains positive is controversial. In this case, genetic, immunophenotypic, and clinical analysis of residual myeloma cells may be necessary to select the effective treatment for the residual myeloma cells. The purpose of this review is to discuss the MM treatment strategy to "cure MM" based on currently available therapies, including IMiDs, PIs, MoAbs, and ASCT, and expected immunotherapies, such as chimeric antigen receptor $\mathrm{T}$ cell (CAR-T) therapy, via improvement of the immunological environment and maintenance of MRD negativity.

Keywords: multiple myeloma; immune environment; minimal residual disease; proteasome inhibitor; immunomodulatory drug; monoclonal antibody; autologous stem cell transplantation

\section{Introduction}

Multiple myeloma (MM) is a hematopoietic malignancy of the plasma cells, and although the survival of patients with MM has been prolonged by the development of new agents in the last few decades, it is still an incurable disease [1,2].

To cure MM, it is important to improve the immune environment and ensure persistent minimal residual disease (MRD) negativity [3-5]. Notably, the immune environment of myeloma patients is characterized by an attenuated immune effect on tumor cells, creating an environment suitable for the survival of myeloma cells $[3,4]$. However, an improved immune environment leads to the long-term survival of patients with myeloma 
due to enhanced immunological potency against myeloma cells [6]. Recently, various immunotherapeutic agents, including immunomodulatory drugs (IMiDs) and monoclonal antibody drugs (MoAbs) against CD38 and signaling lymphocytic activation molecule family 7 (SLAMF7), have been developed [7-11]. In addition, the clinical development of an immune checkpoint inhibitor for myeloma, which has played an important role in the treatment of solid malignant tumors, is under way [12]. Autologous grafts used in autologous stem cell transplantation (ASCT), which is still the standard treatment for patients with MM [13,14], have been reported to improve the immune environment [15].

MRD-negativity, which is analyzed using next-generation sequencing (NGS) and next-generation flow cytometry (NGF), prolongs the progression-free survival (PFS) and overall survival (OS) of patients [5]. Persistent MRD negativity in multiple assessments is important for long-term survival [5]. However, the prognosis of MRD-positive patients is not good, even if complete response (CR) is achieved. Therefore, eradicating all myeloma cells should be the primary treatment goal for MRD-positive patients, although sustained MRD-positivity is not always an unfavorable outcome [16]. Genetic and immunophenotypic characterization of residual myeloma cells, including the clinical course, can be essential for defining and selecting a suitable treatment strategy.

The purpose of this review is to describe the importance of improving the immune environment in MM patients and its therapeutic strategies, the clinical significance of MRD status for long-term survival, and therapeutic strategies for persistent MRD negativity. We also describe the treatment of residual myeloma cells in MRD-positive patients and the future MRD status-adapted treatment strategies.

\section{Immunological Environment in MM}

The immune system plays an important role in the genesis of myeloma. The functions of immune cells are suppressed by cytokines and the interaction between myeloma cells and the bone marrow (BM) microenvironment $[17,18]$. A potential positive relationship between the cellular components of the immune system, such as T cells, natural killer (NK) cells, regulatory T cells (Treg), and B cells, and myeloma progression was suggested in previous studies [17-19]. According to an earlier report, disease status, advanced stage in the International Staging System (ISS), and high-risk cytogenetic abnormalities (HRCA) were related to worse immune profiles [18].

$\mathrm{T}$ cells are categorized into cytotoxic $\mathrm{CD} 8^{+} \mathrm{T}$ cells and helper $\mathrm{CD} 4^{+} \mathrm{T}$ cells. Cytotoxic $\mathrm{T}$ cells (CTL) are effector cells for adoptive immune responses and are activated by interleukin (IL)-2 and exert their anti-tumor effect by releasing interferon-gamma following antigen presentation [19]. $\mathrm{CD}^{+} \mathrm{T}$ cells mainly enhance the adaptive immune response [20]. Tcells are quantitatively and functionally altered in $\mathrm{MM}$ and, consequently, have a role in the immunodeficiency associated with myeloma pathogenesis [21]. The frequencies of effector memory and effector $\mathrm{CD} 8^{+} \mathrm{T}$ cells in MM patients are higher than those in healthy individuals, while the frequency of $\mathrm{CD}^{+} \mathrm{T}$ cells is similar between $\mathrm{MM}$ patients and healthy individuals [22]. Low $\mathrm{CD} 4^{+} \mathrm{T}$ cell counts and low $\mathrm{CD} 4 / \mathrm{CD} 8$ ratios in peripheral blood (PB) are predictors of poor clinical outcomes [23].

$\mathrm{T}$ cells, especially in tumor sites, are exhausted in patients with MM compared to those with monoclonal gammopathy of undetermined significance (MGUS) $[22,24,25]$. T cell exhaustion is induced by inadequate IFN-gamma and upregulation of inhibitory receptors on T cells, such as programmed cell death protein1 (PD-1), cytotoxic T-lymphocyteassociated antigen 4 (CTLA-4), Tim-3, and lymphocyte activation gene-3 (LAG-3), in MM patients $[24,26]$. Galectin-9 and a proliferation-inducing ligand (APRIL) derived from osteoclasts, which constitute the microenvironment of myeloma cells, induce Tim-3 and programmed death-ligand 1 (PD-L1) on MM cells, respectively, and contribute to immune escape [27]. Soluble PD-L1, derived from MM cells, suppresses the immune system by binding to PD-1 on CTL [28]. T cell anergy is a tolerance mechanism due to the inactivation of lymphocytes, and anergic $\mathrm{T}$ cells remain alive for an extended period in a hyporesponsive state [29]. Anergic T cells are induced by co-stimulation of the T cell receptor 
(TCR) and low expression of CD28 and high expression of CTLA-4 on MM cells [24,30]. The positivity of PD- 1 and CTLA- 4 on both $\mathrm{CD} 4^{+}$and $\mathrm{CD} 8^{+} \mathrm{T}$ cells in MM patients was higher than that in healthy individuals in BM [24]. PD-1 ${ }^{+}$lymphocytes contribute to the proliferation of functionally impaired tumor-specific lymphocytes [31]. The high frequency of PD-1- or CTLA-4-expressing CD8 ${ }^{+} \mathrm{T}$ cells was not significantly different in MM patients before and after IMiDs treatment [22]. In addition, PD- $1^{+} \mathrm{CD} 38^{+}$lymphocytes suppress anti-cancer activity and have been identified in patients with malignancies [32], especially after administration of anti-PD-1 MoAbs [33]. Thus, PD-1 and PD-L1 are therapeutic targets in MM.

NK cells are effector lymphocytes for the innate immune response, control several types of tumors and infections, and regulate the activities of T cells, macrophages, and dendritic cells [34]. Elevated NK cell counts in PB and BM are noted in patients with early-phase myeloma, but the number of NK cells in PB decreases as myeloma progresses. Moreover, NK cell activity is reduced in patients with MM [35]. In antibody-dependent cellular cytotoxicity (ADCC) activity induced by the binding of Fc $\gamma$ receptors to the Fc tail of the MoAbs, NK cells release toxic proteins, including granzymes and perforins, which kill myeloma cells [36]. However, myeloma cells have reduced ADCC activity due to downregulated expression of NK cell receptors, such as natural killer group 2D (NKG2D), NKp30, CD244, and DNAX accessory molecule 1 (DNAM-1) [37,38]. In addition, the expression of PD-1 on NK cells prevents immune recognition of tumor cells in myeloma patients [39]. ADCC activity can be induced by several MoAbs, including PD-1 blockade, and is essential for MM treatment.

Treg cells comprise $5-7 \%$ of $\mathrm{CD} 4^{+} \mathrm{T}$ cells and develop from $\mathrm{CD}^{+} \mathrm{T}$ cells under conditions of high levels of transforming growth factor- $\beta$ (TGF- $\beta$ ) [40]. They suppress the immune response in the functional homeostasis of the immune system [35]. Tregs induce immune tolerance by modulating antigen presentation by expressing soluble antiinflammatory mediators, such as IL-10 and TGF $\beta$, the consumption of IL-2, and the expression of negative regulatory cell surface receptors, including CTLA-4 [41,42]. Patients with MM have elevated Treg level, which is a marker of poor prognosis [43-45]. MM cells secrete an inducible T-cell co-stimulator ligand (ICOS-L) and transform non-Tregs into Tregs [46]. Thus, decreasing the Treg count can enhance the immune activity against myeloma cells.

Data on the kinetics of B cells are limited compared with those of $\mathrm{T}$ cells. Decreasing levels of polyclonal immunoglobulin reflect suppression of $\mathrm{CD} 19^{+} \mathrm{B}$ cells, which is inversely correlated with disease progression and affects normal B-cell differentiation [21,47]. TGF- $\beta$ contributes to B-cell dysfunction in myeloma [21,48]. Regulatory B cells (Breg), a small B-cell subset, regulate immune responses via stimulation of IL-10, an anti-inflammatory cytokine, and modulation of $\mathrm{CD} 4^{+} \mathrm{T}$ cell activation and differentiation [49]. Breg induces an immunosuppressive BM microenvironment, which may, in turn, affect therapeutic response and disease outcome in patients with MM [50]. Therefore, Breg inhibition is a potential therapeutic target.

Macrophages are blood cells derived from monocytes and show various activities depending on the body site. Macrophages contribute to antibody-dependent cellular phagocytosis (ADCP) activity, which is the phagocytosis of antibody-opsonized tumor cells via binding to Fc $\gamma$ receptors present on macrophages or monocytes [51]. In contrast, some macrophages suppress immune activity in myeloma. Tumor-associated macrophages (TAMs) are categorized as M2 and have a pro-tumoral function. They infiltrate the tumors and are associated with the growth, angiogenesis, and metastasis of various cancers, including MM [52,53]. TAMs in MM have little cytotoxicity and suppress T cell activity [54]. In addition, TAMs regulate fibroblast function in BM [52] and induce resistance to chemotherapy via inhibition of Bcl-XL-dependent caspase activation [55]. Thus, TAM inhibition is a potential therapeutic target as well. A summary of function of immune cells for healthy individuals and MM patients is shown in Table 1. 


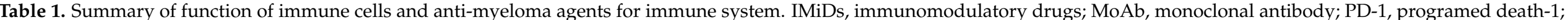

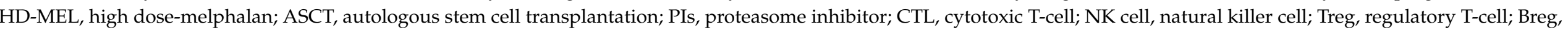

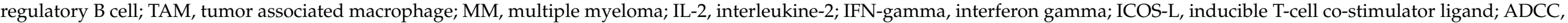
antibody-dependent cellular cytotoxicity; ADCP, antibody-dependent cellular phagocytosis; HMGB-1, high-mobility group box-1; FOXP3, forkhead box P3; and ADO, adenosine.

\begin{tabular}{|c|c|c|c|c|c|c|}
\hline Characteristics & CTL & NK Cell & Treg & Breg & Macrophage & TAM \\
\hline $\begin{array}{l}\text { Function in healthy } \\
\text { individuals }\end{array}$ & $\begin{array}{l}\text { Adoptive immune } \\
\text { responses activated by IL-2 } \\
\text { and anti-tumor effect by } \\
\text { releasing IFN-gamma [19] }\end{array}$ & $\begin{array}{l}\text { Innate immune response, } \\
\text { and regulate the activities of } \\
\mathrm{T} \text { cells, macrophages, and } \\
\text { dendritic cells [34] }\end{array}$ & $\begin{array}{l}\text { Suppression for immune } \\
\text { response via immune } \\
\text { tolerance by modulating } \\
\text { antigen presentation, the } \\
\text { consumption of IL-2, and } \\
\text { the expression of negative } \\
\text { regulatory cell surface } \\
\text { receptors [35,41,42] }\end{array}$ & $\begin{array}{l}\text { Regulation of immune } \\
\text { responses via stimulation of } \\
\text { IL-10 [49] }\end{array}$ & $\begin{array}{l}\text { Various activities } \\
\text { depending on the body site }\end{array}$ & - \\
\hline Function in MM patients & $\begin{array}{l}\text { Exhaustion in tumor site via } \\
\text { upregulation of inhibitory } \\
\text { receptors }[22,24,26]\end{array}$ & $\begin{array}{l}\text { NK cell activity is reduced } \\
\text { in patients with MM [35] }\end{array}$ & $\begin{array}{l}\text { Elevated Treg level predicts } \\
\text { poor prognosis [43-45]; } \\
\text { transformation from } \\
\text { non-Tregs into Tregs by } \\
\text { secretion of ICOS-L [46] }\end{array}$ & $\begin{array}{c}\text { Induction of an } \\
\text { immunosuppressive BM } \\
\text { micro-environment [50] }\end{array}$ & Relation with ADPC [51] & $\begin{array}{l}\text { Suppress T-cell activity [54] } \\
\text { Induction of resistance to } \\
\text { chemotherapy [55] }\end{array}$ \\
\hline Drugs & - & - & - & - & - & - \\
\hline IMiDs & $\begin{array}{l}\text { Activate via INF-gamma } \\
\text { and IL-2 from T-cell from } \\
\text { CD4 }{ }^{+} \text {T-cell and PD-1 } \\
\text { blockade }[56,57]\end{array}$ & $\begin{array}{l}\text { Activate ADCC by } \\
\text { INF-gamma and IL-2 from } \\
\text { CD4 } 4^{+} \text {T-cell }[56,58,59]\end{array}$ & $\begin{array}{l}\text { Inhibit via down regulation } \\
\text { of FOXP3 [60] }\end{array}$ & - & - & $\begin{array}{c}\text { Decrease TAM via } \\
\text { conversion from TAM into } \\
\text { M1 macrophage [61] }\end{array}$ \\
\hline Anti-CD38 MoAb & $\begin{array}{l}\text { Induce clonal increasing } \\
\text { CTL [62] }\end{array}$ & $\begin{array}{l}\text { Decrease CD38 } 8^{+} \mathrm{NK} \text { cell but } \\
\text { activate ADCC by } \\
\text { CD38 } \\
\end{array}$ & $\begin{array}{c}\text { Inhibit activity via } \\
\text { suppression ADO [66-68] }\end{array}$ & $\begin{array}{c}\text { Inhibit activity via } \\
\text { suppression ADO [66-68] }\end{array}$ & Activate ADCP [69] & - \\
\hline Anti-PD-1 MoAb & $\begin{array}{c}\text { Activate via PD-1 } \\
\text { blockade [31] }\end{array}$ & $\begin{array}{l}\text { Activate via PD-1 } \\
\text { blockade [31] }\end{array}$ & - & - & - & - \\
\hline Belantamab Mafodotin & & Activate ADCC [70] & - & - & Activate ADCP [70] & - \\
\hline HD-MEL + ASCT & $\begin{array}{l}\text { Decrease T-cell but activate } \\
\text { via activated dendritic cell } \\
\text { by releasing HMGB1 }[71,72]\end{array}$ & - & $\begin{array}{l}\text { Decrease Treg by } \\
\text { HD-MEL [72,73] }\end{array}$ & - & - & - \\
\hline PIs & - & $\begin{array}{l}\text { Activate ADCC via HLA } \\
\text { class1 blockade }[74,75]\end{array}$ & - & - & - & - \\
\hline
\end{tabular}




\section{Importance of Immunological Environment for Long-Term Survival in MM}

Immune reconstitution, which is indicated by lymphocyte count in PB and immunoglobulin levels, predicts good prognosis in patients with MM. Changes in the BM immune microenvironment have recently been analyzed using cytometry by time of flight (CyTOF) and NGF.

Early immune reconstitution, which is defined as recovery to the normal count of both lymphocytes and monocytes one month after treatment, predicts long OS. The OS in patients with early immune reconstitution was reported to be similar to that in patients without immune deregulation at diagnosis. The frequency of early immune reconstitution is high in patients treated with IMiDs and low in patients with HRCA [76]. The recovery of absolute lymphocyte count (ALC), defined as $\geq 1400$ cells $/ \mu \mathrm{L}$ at day 0 , day 15 , and day 90 after ASCT, predict long OS [15]. Decreased $\mathrm{CD}^{+} \mathrm{T}$ cell count and the CD4/8 ratio are associated with poor prognosis $[23,77]$. The number of clonal CD8 ${ }^{+} \mathrm{T}$ cells, which are identified as effector memory $T$ cells with a restricted T-cell receptor (TCR) V $\beta$ expression, was associated with persistent stimulation by myeloma-associated antigens [78]. The count of clonal $\mathrm{CD}^{+} \mathrm{T}$ cells in PB was higher in myeloma patients who survived for more than 10 years than in those who died in less than 10 years [79]. Among patients with long-term $\mathrm{CR}$ after ASCT, the distribution of $\mathrm{CD}^{+}$and $\mathrm{CD}^{+}$memory $\mathrm{T}$ cells and naïve $\mathrm{B}$ cells in $\mathrm{PB}$ was higher than that in age-matched healthy individuals [80]. In contrast, the presence of naïve and terminally differentiated $\mathrm{T}$ cells in the BM predicted a short survival time in myeloma patients who received ASCT using CyTOF [81]. These results suggested that naïve $T$ cells could not activate antigen engagement, and terminally differentiated $\mathrm{T}$ cells could not mediate effective clearance of myeloma cells because of T cell exhaustion. In the transplant-ineligible patients enrolled in the PETHEMA/GEM2010MAS65 study, PFS and OS were longer in the groups rich in naïve and memory B cells in BM using NGF instead of the ISS and those with cytogenetic abnormality and MRD status [82]. Thus, improving the immune microenvironment is associated with long-term survival and is a surrogate marker for good outcomes in myeloma patients.

Immunoparesis is associated with poor outcomes in patients treated with novel agents and cytotoxic agents [83-85]. In a multivariate analysis including age, ISS stage, and genetic risk of MM patients treated with novel agents, a low immunoglobulin (Ig)M level was a significant predictor of short PFS and OS compared with IgA and IgG levels [83].

The oligoclonal band is often identified in patients with $\mathrm{CR}$ and is an immunoglobulin derived from myeloma cells and other polyclonal B cells [86,87]. In a previous study, the oligoclonal band predicted longer survival and disappeared before relapse [86]. However, in MM patients with extramedullary disease (EMD) or light chain escape, the oligoclonal band may remain. Thus, the oligoclonal band is also considered a form of immune reconstitution [88]. Oligoclonal bands, identified as clonal isotype switches, are often detected after ASCT or chemotherapy [89,90] and predict long-term survival in patients receiving ASCT $[89,91]$. In patients treated with PI or IMiDs induction therapy followed by ASCT, the frequency of oligoclonal bands in the patients treated with IMiDs was higher than in those without IMiDs. The $\mathrm{CD}^{+} \mathrm{T}$ cell count was significantly lower, and the CD4/CD8 $T$ cell ratio was significantly higher in patients with oligoclonal bands than in those without oligoclonal bands [89]. Thus, improvement of immune status concerning $\mathrm{T}$ cells and $\mathrm{B}$ cells predicts good outcomes in MM patients. In addition, immune reconstitution of $\mathrm{T}$ cells could be correlated with that of B cells.

Immune status in BM was similar among healthy individuals, MGUS patients, and MM patients treated with ASCT using CyTOF [92]. Thus, the immune environment in active MM patients is suitable for the proliferation and survival of myeloma cells, while the immune environment in MM patients with remission is unfit for myeloma cells and normal immune cells increases, leading to immune reconstitution. 


\section{Treatment to Improve the Immunological Environment}

Currently, IMiDs, PIs, and MoAbs play an important role in MM treatment. Many studies have demonstrated that IMiDs and MoAbs improve the immunological environment via activation of $\mathrm{T}$ and NK cells and suppression of Tregs. ASCT improves the immunological environment via the supply of autografts and high-dose melphalan (HDMEL). In addition, PIs activate ADCC via the downregulation of human leukocyte antigen (HLA) on myeloma cells. A summary of anti-myeloma agents for immune system is shown in Table 1.

\subsection{IMiDs}

IMiDs induce immune modulation and exhibit anti-myeloma activity. They also enhance both the adaptive and innate immune systems via co-stimulation of $\mathrm{T}$ cells and enhancement of NK in vitro [56]. These drugs enhance the tumor-specific Th1 type immune response via the generation of IFN-gamma and IL-2 derived from $\mathrm{CD}^{+}$and $\mathrm{CD} 8^{+} \mathrm{T}$ cells [56]. Examples of IMiDs include lenalidomide (LEN) and pomalidomide (POM), and thalidomide (THAL). LEN and POM, excluding THAL, augment ADCC and innate cytotoxicity of NK cells and promote the proliferation of NK cells dependent on IL-2 [58]. LEN and POM upregulate the expression of FasL and Granzyme B on NK cells [59]. In addition, IMiDs suppress Treg function by downregulating Foxp3 gene expression in Tregs [60]. The effect of IMiDs depends on cereblon (CRBN) burden concerning both direct antitumor effects and immune activity [93]. IMiDs also act on immune checkpoint molecules to enhance immune responses. They suppress PD-1 expression on T and NK cells [57], and LEN suppresses PD-L1 expression in MM cells [43]. Finally, LEN coverts M2 macrophages, identified as TAM, into M1 macrophages via the degradation of the IKAROS family zinc finger 1 (IKZF1) of macrophages [61]. Iberdomide (IBER), a next-generation cereblon-targeting agent, showed direct anti-myeloma activity for LEN- and/or POMresistant human myeloma cell lines via faster degradation of IKZF1 due to high cereblonbinding affinity and enhanced immunomodulatory effect in a co-culture with peripheral blood mononuclear cells via elevated IL-2 secretion and granzyme-B degranulation [94,95]. In addition, IBER combined with daratumumab (DARA) enhanced complement-dependent cytotoxicity (CDC) compared with either drug alone [95], demonstrating the clinical efficacy of IMiDs and/or anti-CD38 MoAb in refractory MM patients [96].

\subsection{MoAbs}

Daratumumab (DARA) is a monoclonal antibody against CD38 antigen with complementdependent cytotoxicity (CDC) and enhanced ADCC activities [63]. CD38 is expressed on the surface of myeloma cells as well as T and NK cells [62]. Notably, DARA reduces NK cell count [64]. However, CD38 $8^{-/ \text {low }}$ NK cells play a major role in ADCC activity, an immune response that is expected even after DARA administration [65]. DARA also contributes to a clonal increase in CTL and suppression of Treg and Breg [62]. DARA-containing treatment is an option for post-transplant treatment as it might reduce the number of CD38 $8^{+}$Treg, which increases early after ASCT and suppresses the immune effect [62]. In the POLLUX trial, the clonal expansion of $\mathrm{CD} 8^{+} \mathrm{T}$ cell and reduction of $\mathrm{CD} 38^{+}$Treg were observed more frequently in the deep responders treated with DRd (DARA, LEN, plus dexamethasone (DEX)) than in those treated with Rd (LEN plus DEX) [97]. Anti-CD38 MoAbs also activate $T$ cell function via suppression of adenosine (ADO) production because CD38 functions as an ectoenzyme and promotes $\mathrm{ADO}$ production from $\mathrm{NAD}^{+}$via regulation of calcium signaling, which suppresses $\mathrm{T}$ cell activity [66-68]. Isatuximab (ISA), a new anti-CD38 $\mathrm{MoAb}$, has been approved for relapsed/refractory MM (RRMM). Similar to DARA, ISA can also modulate the immune system. ISA has a higher direct killing activity of myeloma cells [98] but lower CDC activity than DARA [99]. A combination of ISA and POM showed higher anti-myeloma activity than a combination of ISA and LEN [98].

Anti-PD-1 MoAb is expected to be active against several solid malignancies because PD-1-expressing lymphocytes expand tumor-specific CTLs and suppress the anti-myeloma 
activity [31]. In the KEYNOTE-185 trial, PFS of patients in the pembrolizumab, an anti-PD-1 $\mathrm{MoAb}$, plus Rd group was similar to that of patients in the Rd group, while severe adverse events and treatment-related mortality of patients in the pembrolizumab plus Rd group were higher than those of patients in the Rd group [100].

CD38/PD-1 double-positive lymphocytes have been identified in patients with malignancies [32]. CD38 expression on T cells might induce escape from PD-1/PD-L1 blockade in tumor cells [33]. However, in a previous study, durvalumab, an anti-PD-L1 MoAb, and daratumumab were ineffective in myeloma patients with daratumumab refractoriness [101]. A clinical trial on combined anti CD38 and PD-1 monoclonal antibodies for myeloma patients is ongoing.

Belantamab mafodotin is the first anti-B-cell mature antigen (BCMA) antibody drug conjugate (ADC) with mono methyl auristatin $\mathrm{F}$ (MMAF) and has been approved for RRMM in the United States [102]. Belantamab mafodotin not only delivers MMAF into the BCMA-expressed myeloma cells and induces apoptosis but also enhances ADCC and $\mathrm{ADCP}[70]$.

\subsection{ASCT}

The therapeutic effect of ASCT depends on HD-MEL therapy for MM. However, autografts play an important role in the therapeutic effect of ASCT. Granulocytes, platelets, and red blood cells recover within a few weeks, while the recovery of other blood cells, such as lymphocytes and monocytes, takes a longer duration after HSC transplantation [103]. Immune reconstitution, which has been shown to increase absolute lymphocyte count, CD4/CD8 ratio, and oligoclonal band, is associated with good clinical outcomes in patients receiving ASCT [15,77,79-81,89].

HD-MEL is the mainstay of pre-transplantation conditioning chemotherapy. HD-MEL induces lymphodepletion, which could affect immunological activity, including that of $\mathrm{T}$ cells, in myeloma cells [71]. However, T cell count from autografts is upregulated by IL-7 and IL-15, whose serum levels increase after HD-MEL followed by ASCT, although $\mathrm{T}$ cell count decreases in the absence of these cytokines [71]. Melphalan has been shown to activate $\mathrm{CD} 8^{+} \mathrm{T}$ cells via dendritic cell activation due to immunogenic cell death and antigen presentation, including the release of high-mobility group box 1 (HMGB-1), in myeloma-bearing mice [72]. In addition, the combination of melphalan and $\mathrm{CD} 4^{+} \mathrm{T}$ cell adoptive cell therapy is more effective than either treatment alone in mice. HD-MEL can enhance immune activity by reducing the levels of Treg and myeloid-derived suppressor cells, which inhibit the anti-myeloma T cell-mediated immune response in BM [72,73].

\subsection{Proteasome Inhibitors}

PIs enhance ADCC activity by suppressing HLA class 1 expression on MM cells [74]. Recently, bortezomib, a proteasome inhibitor, enhanced the ADCC of DARA in mice when human myeloma cell lines and ex vivo NK cells were co-cultured [75]. Additionally, PIs activate dendritic cells by increasing exposure to tumor antigens, thus inducing immunogenic cell death $[104,105]$.

\section{Clinical Significance of MRD Negativity in MM}

MRD can be analyzed in patients who have achieved CR using NGF or NGS. Immunophenotypic and molecular CR are defined as achievement of MRD negativity using NGF and NGS, respectively, according to the International Myeloma Working Group recommendation [106]. Several reports indicate that achievement of negative MRD is associated with prolonged PFS and OS, but the curability of MM is still debatable [107,108]. According to a recent meta-analysis, MRD negativity predicted long PFS and OS independent of transplant eligibility, disease status, cytogenetic risk, MRD sensitivity threshold, and MRD detection methods [5]. A summary of phase 3 clinical trials investigating MRD status was shown in Table 2. 


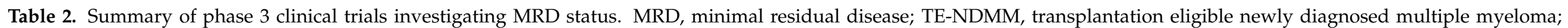

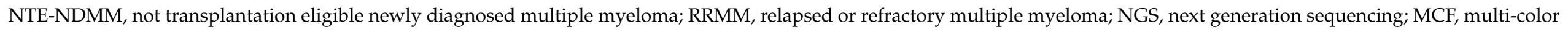

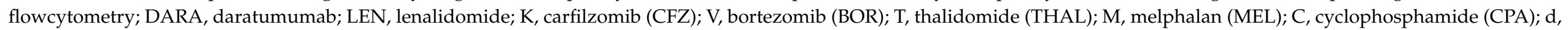

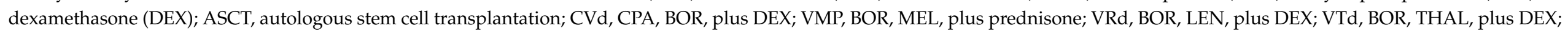

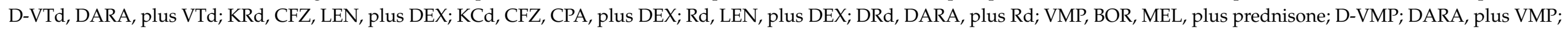

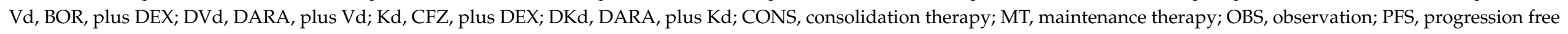
survival; OS, overall survival; NR, not reached; and mo, months.

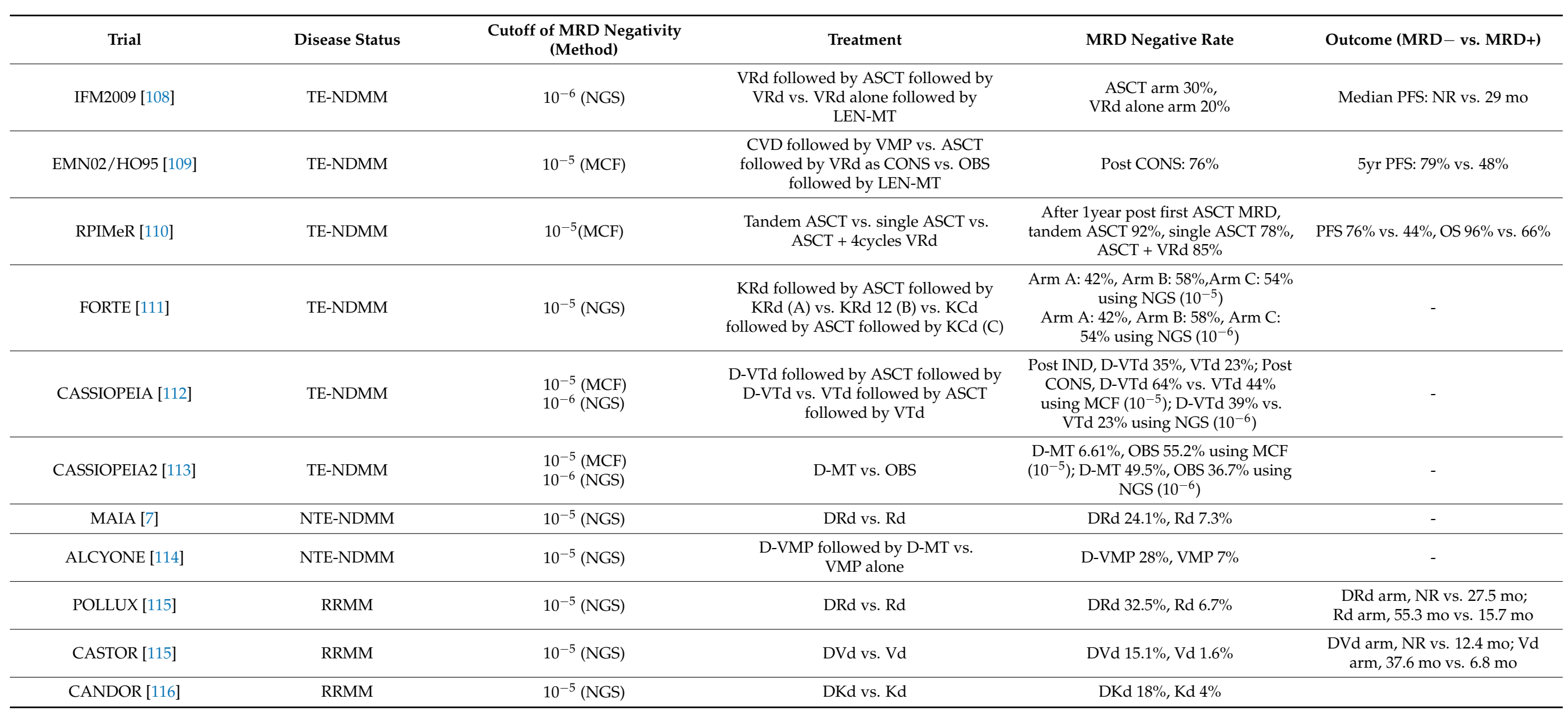


In a phase 2 trial on LEN maintenance therapy after ASCT, no relapse was noted in patients with sustained MRD negativity for two years after a median follow-up time of 40.7 months, while the PFS in patients with loss of MRD negativity was shorter than in those with persistent MRD positivity [16]. MRD status might affect decisions regarding treatment discontinuation or escalation/de-escalation of treatment intensity [117], and several response-adapted clinical trials on MRD are ongoing [118]. Thus, MRD negativity is an important prognostic factor for long-term survival and a biomarker of the treatment strategy.

MRD status is assessed using BM samples of myeloma patients, but the invasiveness of BM tests has necessitated the use of PB samples [119-121]. Although MRD assessment using PB samples is less invasive, it is less accurate than using BM samples. Nevertheless, MDS-negativity using PB samples can predict survival in myeloma patients $[119,120]$. Meanwhile, MRD status using PB might reflect not only residual myeloma cells in the BM but also EMD due to the detection of circulating residual myeloma cells [121]. Therefore, we considered that the use of PB samples is suitable for checking MRD-negativity, while the use of BM samples is necessary for evaluating precise MRD-negativity. Sustained MRD-negativity is important for long-term survival among myeloma patients, but it is controversial whether BM and PB samples are suitable for assessing sustained MRDnegativity. There is no consensus about the optimal timing of the next treatment for patients whose MRD status has changed from negative to positive. We consider that PB samples may be more suitable than BM samples for analysis of sustained MRD-negativity because MRD status using PB reflects residual myeloma cells in not only testing site of BM but also the other sites including EMD.

\section{Current Treatment to Achieve Persistent MRD-Negativity}

High-dose chemotherapy followed by ASCT was developed in the 1990s and is still a standard treatment for patients with MM. In addition, various treatment agents, including IMiDs, PIs, and MoAbs, have been developed in the last two decades, thus increasing $\mathrm{CR}$ ratios [1,2]. Many clinical trials have demonstrated that the administration of several treatment agents with different modes of action helps achieve MRD negativity in addition to $C R[5,7,8,111,112,114,115,122-124]$. For MM patients who achieve MRD negativity after induction therapy and ASCT, consolidation and/or maintenance therapy is needed to enhance and maintain the therapeutic effect.

Combination chemotherapies with PIs and IMiDs might induce MRD negativity more frequently than PIs or IMiDs alone for newly diagnosed multiple myeloma (NDMM) and RRMM, although there was no direct comparison between them [122,123]. ASCT and DARA play an important role in achieving MRD negativity after administration of PIs and IMiDs combination chemotherapies [7,14,111,112,114,115,124]. However, no clinical trials have compared up-front ASCT and DARA-containing treatments for NDMM. Considering the improvement of the immune environment after ASCT [125], IMiDs should be one of the best treatment choices. According to a meta-analysis, LEN maintenance therapy prolonged PFS and OS [126,127]. In addition, LEN maintenance therapy achieved and maintained MRD negativity compared with no maintenance therapy [128]. In the TOURMALINE-MM3 trial, post-transplantation ixazomib maintenance therapy prolonged PFS and prevented conversion from MRD negative to positive compared with placebo in MRD-negative patients before maintenance therapy [129]. Moreover, use of MoAbs for consolidation and/or maintenance therapies has been studied [13,112,130]. However, in the CASSIOPEIA trial, the clinical significance of DARA maintenance therapy was relatively low in patients treated with D-VTD (DARA, BOR, THAL, and DEX) therapy as induction therapy compared with those treated with VTD therapy [131]. Thus, further studies are needed on DARA maintenance therapy regarding the duration and timing of discontinuation. 


\section{Characteristics of Residual MM Cells in MRD Positive Patients}

Combination treatment of several agents with different modes of action, including ASCT, contributes to the achievement of MRD negativity. Some clinical trials concerning MRD status-adapted treatment strategies are currently ongoing (Table 3). The MASTER trial investigated the efficacy of four cycles of D-KRd (DARA, CFZ, LEN, plus DEX) followed by ASCT and eight cycles of D-KRd consolidation treatment in achieving MRD negativity for NDMM [132]. If MRD negativity was achieved, chemotherapy was discontinued. Approximately $62-78 \%$ of patients achieved MRD negativity after the treatment, including eight cycles of consolidation therapy, and treatment could be discontinued. However, some patients do not achieve MRD negativity due to the presence of residual myeloma cells that are resistant to the administered treatment. Such patients might require a change of treatment strategy; however, to our best knowledge, no MRD status-adapted treatment strategy has been established. In addition, the clinical significance of pre-emptive therapy for RRMM with conversion from MRD negativity to positivity has not been analyzed to date. The PREDATOR trial is investigating the efficacy of pre-emptive therapy for patients with RRMM who have achieved MRD negativity after the last chemotherapy and may reveal the improvement of survival time of patients with RRMM whose MRD status converted to positivity [NCT03697655]. Therefore, it is important to understand the characteristics of residual myeloma cells and select suitable treatment strategies. Previous reports have demonstrated that residual myeloma cells are immature, have low CD38 expression, and are rich in integrin-related antigens $[133,134]$. Thus, it has been suggested that residual myeloma cells may be resistant to ongoing chemotherapy through adhesion to bone marrow stromal cells (BMSCs) and have some advantages, such as growth, proliferation, survival, and resistance to chemotherapy $[134,135]$. In addition, a previous study reported that when the residual myeloma cells among patients who received VMP (BOR, melphalan, and prednisone) and alternate treatment with VMP and Rd were analyzed by flow cytometry, the incidence of surface antigen changes from the time of diagnosis to MRD assessment in the VMP alone group was higher than in the alternative treatment group [134]. These data suggest that the use of several therapeutic agents might reduce acquired chemotherapy resistance. 


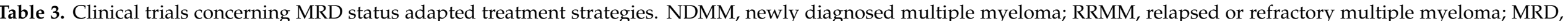

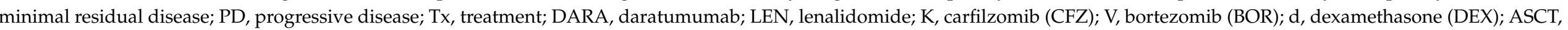

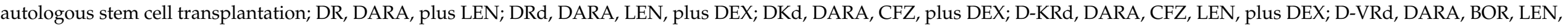
plus DEX; and IMWG, international myeloma working group.

\begin{tabular}{|c|c|c|c|c|}
\hline & Phase & Disease Status & Study Design & Primary Endpoint \\
\hline $\begin{array}{l}\text { DRAMMATIC } \\
\text { (NCT04071457) }\end{array}$ & 3 & NDMM & $\begin{array}{l}\text { DR versus LEN alone maintenance after ASCT (randomization1). If } \\
\text { MRD+, maintenance Tx continues. If MRD-, maintenance Tx } \\
\text { continue versus stop (randomization } 2 \text { ). }\end{array}$ & $\begin{array}{l}\text { Overall survival between DR and } \\
\text { LEN alone }\end{array}$ \\
\hline $\begin{array}{c}\text { MASTER } \\
(\text { NCT03224507) }\end{array}$ & 2 & NDMM & $\begin{array}{c}\text { D-KRd } 4 \text { cycles followed by ASCT; consolidation Tx, D-KRd } \\
8 \text { cycles; maintenance Tx, LEN alone until PD. If MRD- achieved } \\
\text { after ASCT, } 4 \text { or } 8 \text { cycles of D-KRd as consolidation Tx, treatment } \\
\text { free observation. }\end{array}$ & $\begin{array}{l}\text { MRD - rate at the completion of } \\
\text { consolidation Tx }\end{array}$ \\
\hline $\begin{array}{c}\text { DART4MM } \\
(\text { NCT03992170) }\end{array}$ & 2 & NDMM & $\begin{array}{l}\text { DARA monotherapy every week in 1-8 weeks and every } 2 \text { weeks in } \\
\text { 9-24 weeks. If MRD+, DARA every } 4 \text { weeks for } 80 \text { weeks; if MRD-, } \\
\text { DARA stop. }\end{array}$ & Overall response rate \\
\hline (NCT04140162) & 2 & NDMM & $\begin{array}{l}\text { Induction Tx, DRd 1-24 weeks; consolidation Tx, D-VRD for only } \\
\text { MRD+ 25-36weeks; maintenance Tx, DR 37-88 weeks followed by } \\
\text { LEN alone until PD. }\end{array}$ & $\begin{array}{l}\text { MRD - rate after induction and } \\
\text { consolidation } \mathrm{Tx}\end{array}$ \\
\hline $\begin{array}{l}\text { PREDATOR } \\
\text { (NCT03697655) }\end{array}$ & 2 & RRMM & $\begin{array}{c}\text { Pre-emptive DARA until PD versus observation for MRD+ RRMM } \\
\text { after MRD- by last line chemotherapy. }\end{array}$ & Event-free survival \\
\hline
\end{tabular}




\section{Drug Resistance concerning Gene Mutation}

To date, few reports have examined the genetic characteristics of residual myeloma cells [136]. Possibly, the residual myeloma cells in MRD-positive patients on LEN maintenance therapy are resistant to LEN due to decreased CRBN burden, CRBN gene mutation, and $c-M Y C$ overexpression [136-139]. IMiDs may not be effective against residual myeloma cells with reduced CRBN burden and $C B R N$ gene mutations. In these cases, chemotherapy with a different mechanism of action, such as PI or MoAb, should be selected. PI is a therapeutic option for residual myeloma cells with refractoriness for LEN via $c-M Y C$ overexpression because PI has been reported to have a therapeutic effect in patients with $c-M Y C$ overexpression [140-142]. MRD positivity during PI maintenance therapy means that the residual myeloma cells may be resistant to PIs. One of the causes of refractoriness to PIs is proteasome 20S subunit beta 5 (PSMB5) gene mutations [136,143]. Notably, a previous study found that the frequencies of gene mutations concerning refractoriness to LEN or PIs were low, suggesting that these mutations were detected in subclonal myeloma cells, and the clinical significance of these mutations, including gene mutation-guided treatment strategy, should be analyzed in future studies [144].

The causes of resistance to anti-CD38 MoAbs are categorized into decreased or loss of CD38 expression, neutralization of CD38, and decreased immunological effects, including $\mathrm{ADCC}, \mathrm{CDC}$, and $\mathrm{ADCP}$, via reduced numbers of NK cells, complement inhibitory proteins, and CD47 expression on myeloma cells, respectively [145]. CD38 expression decreased in myeloma cells just after DARA was administered and recovered approximately six months after DARA was discontinued [146]. In a phase 2 trial of ISA monotherapy in the RRMM with refractoriness to DARA, a high CD38 expression was associated with a long interval from the last DARA administration, and the disease control rate was higher in the six months or longer DARA-free interval group than in the three months or shorter DARA-free interval group [147]. In the ICARIA-MM trial, the PFS of DARA as the first subsequent therapy in the ISA and POM plus DEX (Pd) group was shorter than that in the $\mathrm{Pd}$ group [148]. Thus, the efficacy of anti-CD38 MoAb could be related to the anti-CD38 free interval, and the immunophenotypic characteristics of residual myeloma cells could predict resistance to anti-CD38 MoAbs.

\section{Immunological Treatment to Eradicate Residual MM Cells}

Residual myeloma cells acquire drug resistance via gene mutation and immune escape. Thus, an immunological approach can be essential for eradicating residual myeloma cells. The commonly used immunotherapy is allogeneic hematopoietic stem cell transplantation (HSCT) up to a few years ago. Treatment of young high-risk myeloma patients with allogeneic HSCT using reduced-intensity conditioning treatment after up-front ASCT has been investigated for several decades, but there is no consensus on whether these treatment strategies can prolong survival [149]. Two clinical trials have revealed long survival of patients treated with ASCT followed by allogeneic HSCT compared to those treated with tandem ASCT $[150,151]$. In contrast, a clinical trial on allogeneic HSCT upfront ASCT reported that OS in patients who received allogeneic HSCT was similar to that in patients who received ASCT alone because some patients experienced recurrence and transplantrelated mortality after allogeneic transplantation [152]. Therefore, other immunotherapies are required. Since PD-L1 is highly expressed in residual myeloma cells in MRD-positive patients [153], the inhibition of immune checkpoints via blocking PD1/PDL1 is expected. Although several reports of post-ASCT treatment with pembrolizumab have shown tolerability, no therapeutic effect or survival benefit has been demonstrated [154,155].

Chimeric antigen receptor T cell (CAR-T) is a new treatment option as immunotherapy and is currently approved by the US FDA (Food and Drug Administration) for patients with RRMM. Several clinical trials are investigating the efficacy and tolerability of CAR-T as an earlier line of treatment such as consolidation therapy [156]. The most popular target antigen for CAR-T is the BCMA, which is specifically expressed in myeloma cells [156-159]. The clinical outcome of CAR-T cells is associated with the quality of harvested autologous 
T-cells $[160,161]$. In a clinical trial for RRMM, anti-BCMA CAR-T expansion and response were related to the preserved $\mathrm{CD} 4 / 8$ ratio and high levels of naïve and stem cell memory $\mathrm{T}$ cells during mobilization and CAR-T manufacturing $[145,146]$. The T-cells suitable for CAR-T were identified more frequently in early-phase MM patients than in heavily treated MM patients [162]. Thus, post-ASCT is one of the best timings for immune therapy, including CAR-T.

Bispecific T-cell engager (BiTE) is an important immunotherapy option. Generally, BiTE is more tolerable than CAR-T, considering the incidence of cytokine release syndrome and neurological toxicity, and less effective than CAR-T according to the results of clinical trials, although no clinical trial has directly compared the two therapies [163]. BiTE might be suitable for MRD-positive patients after ASCT because the immune environment is improved by the autograft. The excellent therapeutic effect of anti-BCMA CAR-T is clear, as evidenced by the high MRD negativity rate, but the PFS is not as long as expected [158]. The resistance mechanisms to anti-BCMA CAR-T include immune escape through reduced expression or disappearance of BCMA on the surface of myeloma cells $[164,165]$. To maintain MRD negativity, continuous stimulation of CAR-T cells could be important. Considering this suggestion, clinical trials on the addition of IMiDs after CAR-T are under way [166]. It has also been reported that the use of BiTE after CAR-T treatment stimulates CAR-T cells and reactivates the immune response. In addition, anti-CD19 and BCMA dual CAR-T was developed to overcome the resistance due to exhaustion of CAR-T cells [167]. In the future, it may be necessary to develop a treatment strategy for maintenance of immune activation with IMiDs, MoAb, or BiTE after CART for the purpose of maintaining MRD negativity.

\section{Correlation between MRD Status and Immune Environment}

Both the immunological environment and MRD-negativity are essential for long-term survival in patients with MM. The immunological environment may be associated with the MRD status [168]. Previous studies reported that the number of TAM, erythroblasts, Tregs, memory B cells, and CD4 $4^{+} \mathrm{T}$ cells (especially CD27 ${ }^{+}$) in BM of MRD-positive patients were significantly higher than those in BM of MRD-negative patients [18,82]. Notably, the number of immune cells in PB does not reflect that in BM [18]. Effector Treg, a form of Treg that strongly suppresses immune activity in myeloma cells, exists in the BM tumor site, although there is no significant difference in Treg counts in PB and BM $[168,169]$. In patients who received ASCT followed by LEN maintenance therapy, NK cells decreased, and exhausted T cells increased in PB of MRD-positive patients compared with that of MRD-negative patients [170]. In addition, the expression of killer cell immunoglobulin like receptor, 2 Ig domains and short cytoplasmic tail 4 (KIR2DS4), which activates immunity, decreased, and that of NKG2A, which suppresses immunity, increased in the MRD-negative patients compared with the MRD-positive patients [170]. Thus, improving the immune environment can contribute to the achievement of MRD, and eradicating residual myeloma cells can balance the immune environment. The correlation between disease status, including MRD status, and immunological environment is shown in Figure 1. 


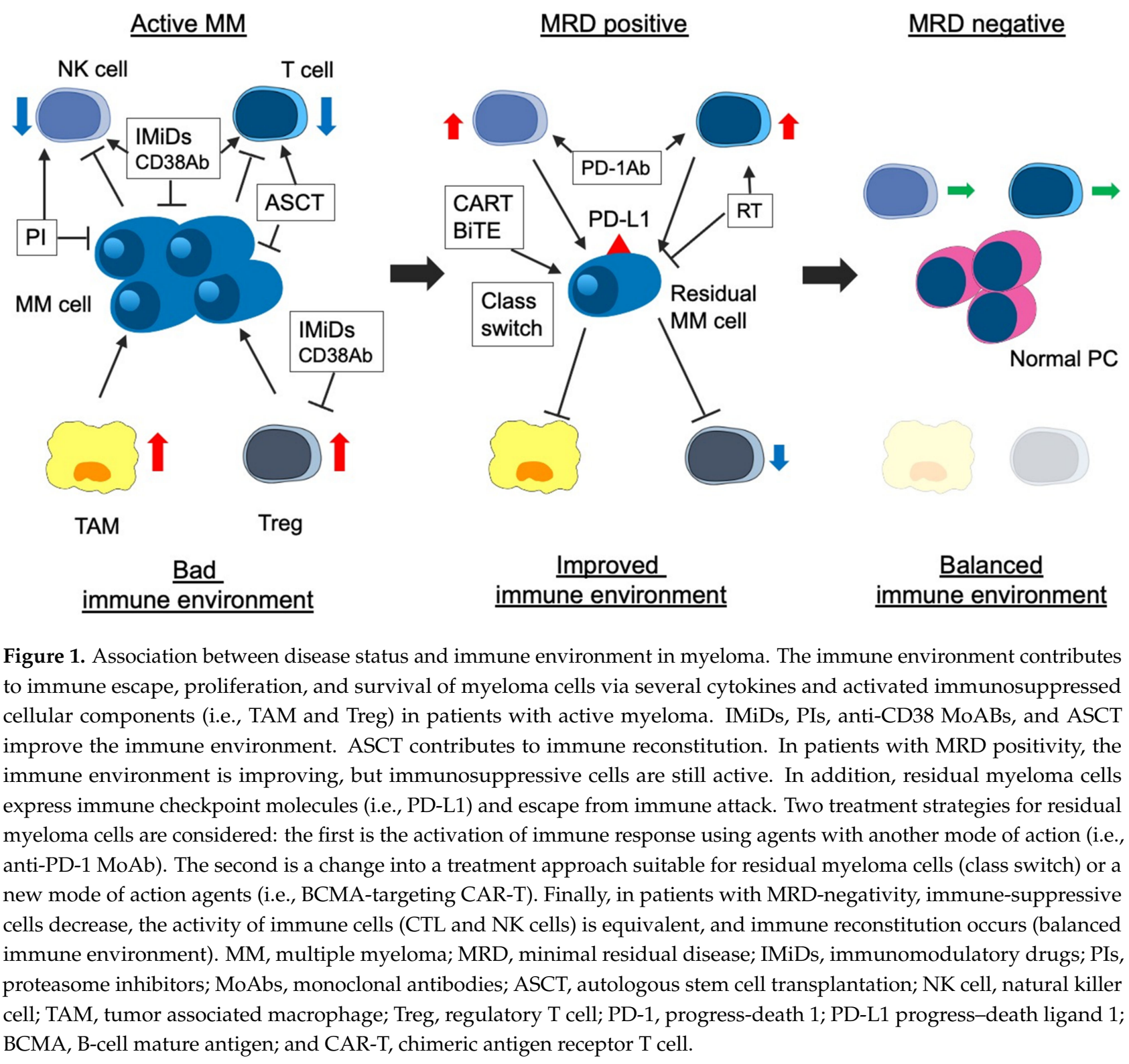

\section{Future Directions}

IMiDs, PIs, MoAbs, and ASCT are important for improving the immune environment and maintaining MRD negativity. We previously reported that the total therapy approach combining these four treatment approaches could be essential, considering the BM microenvironment, such as adhesion to BMSCs, vascular niche, and endosteal niche [171]. If MRD-negativity is achieved, current treatment should continue, although the timing of treatment discontinuation is still controversial. However, immune-activating agents, such as IMiDs, anti-CD38 MoAb, or anti-PD-1 MoAb, might be suitable because the immune environment is equivalent in patients with MRD negativity. If MRD status is positive, the characteristics of residual myeloma cells, such as genetics and immunophenotypes, should be analyzed to optimize treatment. In particular, we considered that assessing MRD status using PB samples might be more suitable for optimizing treatment than using BM samples because MRD status using PB samples can reflect both residual myeloma cells in testing site of BM and the other sites, including EMD [121]. Besides, the use of PB sample eases analysis of residual myeloma cells, and the immunological microenvironment might be activated compared with those in patients with active disease or MRD negativity. Treatment 
algorithm concerning MRD and immunological status for NDMM when anti-CD38 MoAb, IMiDs, and PIs are available was shown in Figure 2.

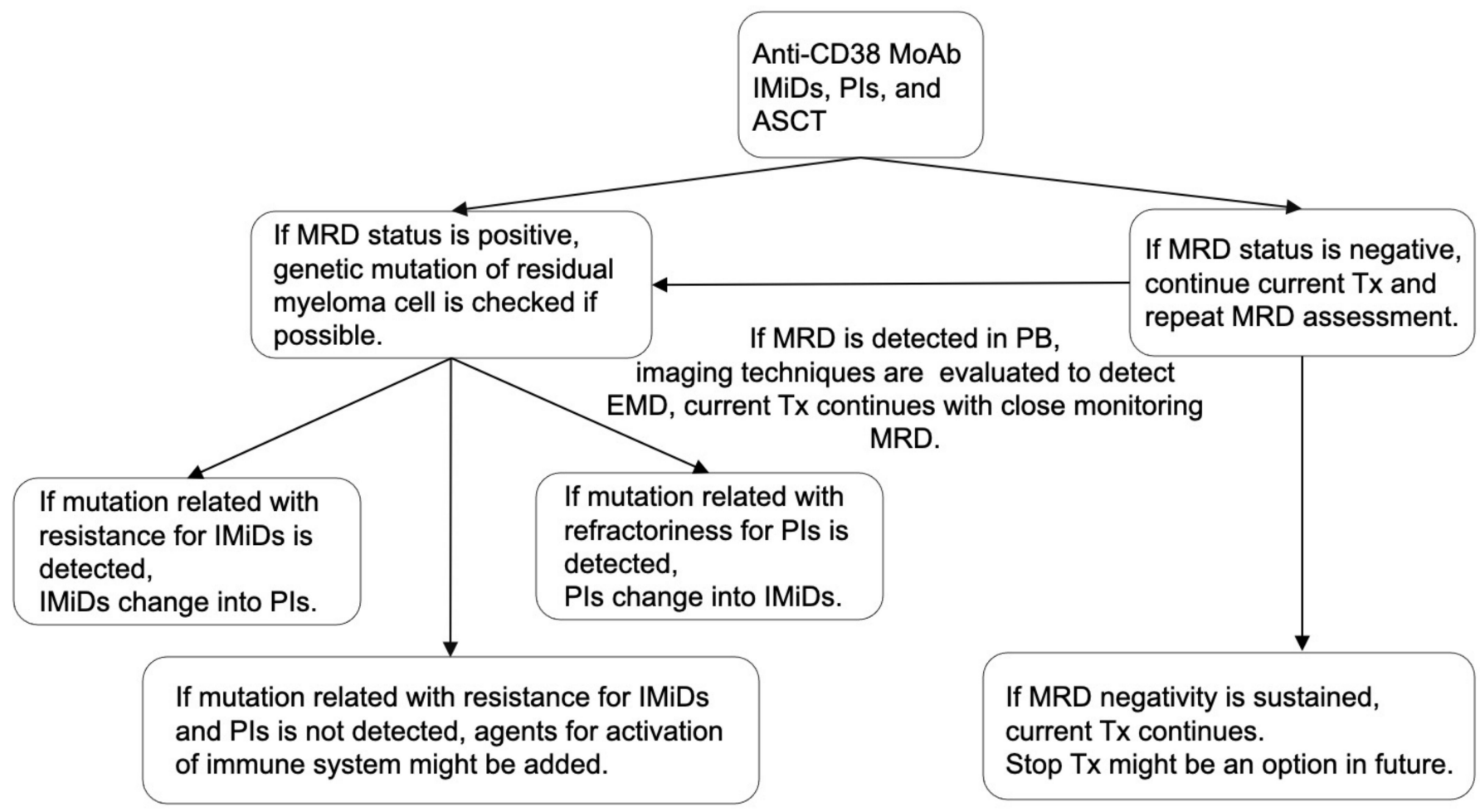

Figure 2. Treatment algorithm concerning MRD and immunological status. Combination therapy with anti-CD38 MoAb, IMiDs, PIs, and ASCT may be suitable for MM patients considering the efficacy against myeloma cells and improved immune system. If the MRD status is negative, the current treatment should continue. However, if the MRD status is positive, the genetic mutation of residual myeloma cells should be analyzed to optimize treatment. If mutation related with resistance for IMiDs or PIs is detected, treatment should be changed. If mutation related with resistance for IMiDs or PIs is not detected, agents for activation of immune system might be added. MRD assessment should be repeated in the patients with MRD negativity. If MRD status convert into positivity in PB sample, imaging technique should be evaluated to detect EMD. Thereafter, the current Tx could continue with close monitoring MRD status. MRD, minimal residual disease; IMiDs, immunomodulatory drugs; PIs, proteasome inhibitors; MoAbs, monoclonal antibodies; ASCT, autologous stem cell transplantation; Tx, treatment; PB, peripheral blood; and EMD, extramedullary disease.

If anti-BCMA CAR-T is available, these agents may be reasonable considering their different modes of action. Meanwhile, immune-activating agents, except anti-PD-1 MoAb, may not be effective because the immune environment is still activated in patients with MRD positivity. Blockade of PD-1/PD-L1 may be necessary as residual myeloma cells express PD-L1. The treatment strategies considering the MRD status are shown in Figure 3. However, analysis and characterization of residual myeloma cells are currently difficult in most hospitals, underscoring the need to consider the resistance to the current antimyeloma agents. For example, if MRD status is positive during LEN maintenance therapy, the treatment can be changed, including class switching, considering decreased CBRN burden, CBRN mutation, and/or c-MYC upregulation. However, it has also been argued when the treatment should be changed during persistent MRD-positivity considering the possibility of a late responder to current treatment. Data from clinical trials on the current MRD-driven treatment will provide more insights into the effective treatment approaches [172]. 


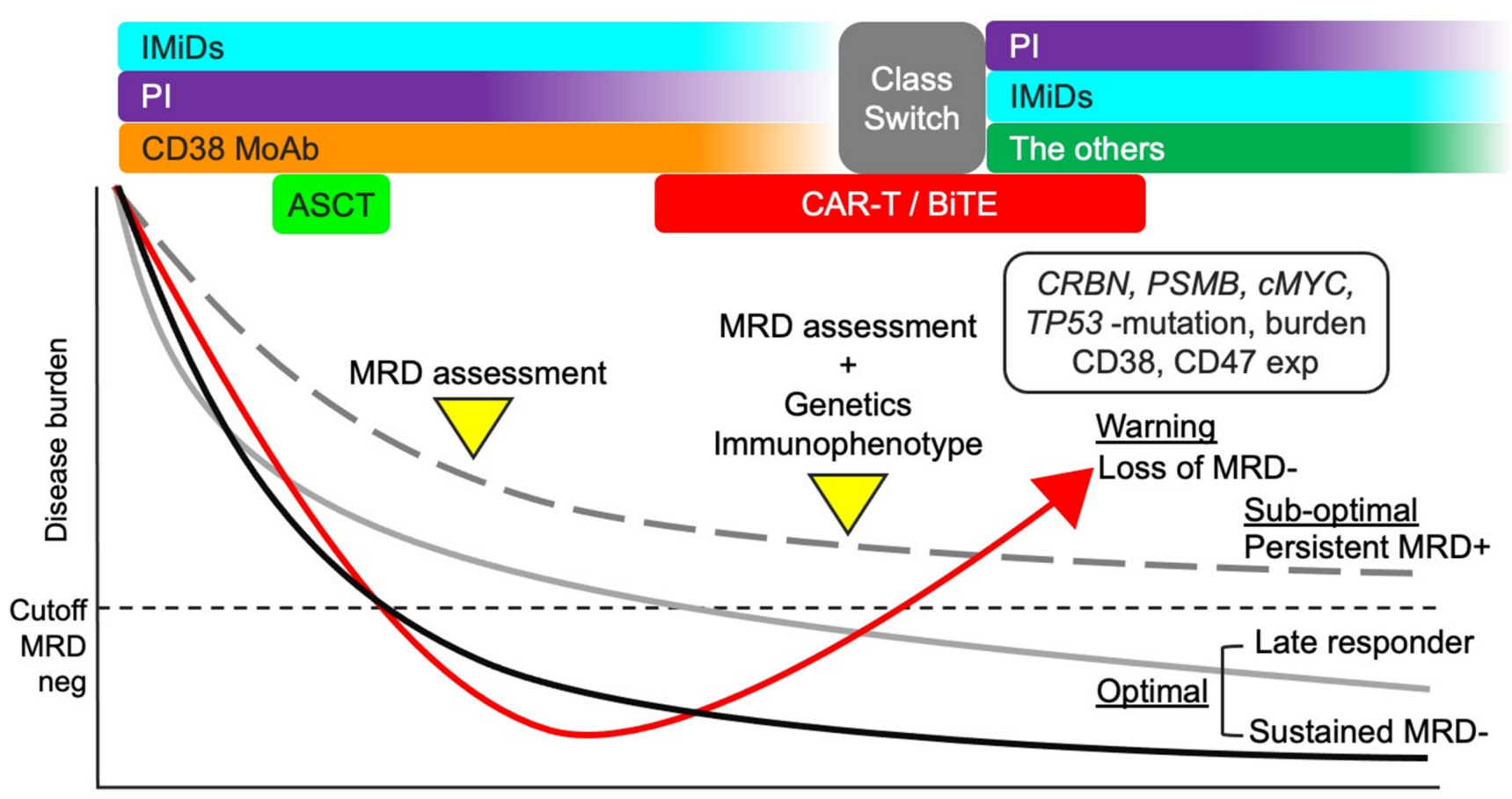

Time

Figure 3. Treatment strategy considering MRD status. A total therapy approach combining IMiDs, PIs, anti-CD38 MoAb, and ASCT may be suitable for MM patients considering the efficacy against myeloma cells and improved microenvironment. MRD status after the total therapy approach can be useful in further treatment decisions. If the MRD status is negative, the current treatment should continue (optimal). However, if the MRD status is positive, the genetic and immunophenotypic characteristics of residual myeloma cells should be analyzed to optimize treatment. Loss of MRD negativity can lead to aggressive recurrence (warning). The clinical outcome of persistent MRD positivity is better than that of loss of MRDnegativity (sub-optimal). Repeated MRD assessment may be necessary for patients with persistent MRD positivity to identify late responders and detect early-phase recurrence. MM, multiple myeloma; MRD, minimal residual disease; IMiDs, immunomodulatory drugs; PIs, proteasome inhibitors; MoAbs, monoclonal antibodies; ASCT, autologous stem cell transplantation; CAR-T, chimeric antigen receptor T cell; CRBN, cereblon; PSMB5, proteasome 20S subunit beta 5; and exp, expression.

Examining the improvement of the immune environment is difficult in current practice, but it can be predicted using recently reported indicators, such as the lymphocyte to monocyte ratio (LMR) [173-175]. A high LMR status reflects a good immunological environment and is associated with a long survival time among MM patients. Recently, we demonstrated that PFS in patients with both MRD-positivity and low LMR status was significantly shorter than in those with MRD-negativity and/or high LMR status, despite the achievement of CR [176]. Thus, a treatment change might be considered in patients with both MRD positivity and low LMR status. However, there is no current evidence showing the clinical significance of changing treatment approaches to enhance the treatment response and improve the immune environment.

\section{Conclusions}

We consider that improvement of the immune environment and maintenance of MRD negativity are key factors for the long-term survival of MM patients. Considering the microenvironment around myeloma cells, initial treatment encompassing IMiDs, PIs, anti-CD38 MoAb, and ASCT is important. This total therapy approach can improve the immune environment and help achieve MRD negativity. This review suggests that an MRD-driven treatment strategy may be promising, but genetic and immunophenotypic analyses of residual myeloma cells should be repeated to select a suitable treatment for residual myeloma cells. Before these analyses are available in clinical practice, treatment 
can be selected based on "class switch." In the future, there is a need to develop a treatment strategy that not only treats the myeloma cells but also improves the immune environment and targets the residual myeloma cells.

Author Contributions: Conceptualization, K.S.; writing-original draft preparation, K.S.; writingreview and editing, K.S.; supervision, K.N. and S.Y. All authors have read and agreed to the published version of the manuscript.

Funding: This research received no external funding.

Institutional Review Board Statement: Not applicable.

Informed Consent Statement: Not applicable.

Data Availability Statement: No new data were created or analyzed in this study. Data sharing is not applicable to this article.

Conflicts of Interest: The authors declare no conflict of interest.

\section{References}

1. Palumbo, A.; Anderson, K. Multiple myeloma. N. Engl. J. Med. 2011, 364, 1046-1060. [CrossRef]

2. Van de Donk, N.W.C.J.; Pawlyn, C.; Yong, K.L. Multiple myeloma. Lancet 2021, 397, 410-427. [CrossRef]

3. Bębnowska, D.; Hrynkiewicz, R.; Grywalska, E.; Pasiarski, M.; Sosnowska-Pasiarska, B.; Smarz-Widelska, I.; Góźdź, S.; Roliński, J.; Niedźwiedzka-Rystwej, P. Immunological Prognostic Factors in Multiple Myeloma. Int. J. Mol. Sci. 2021, 22, 3587. [CrossRef] [PubMed]

4. Leone, P.; Solimando, A.G.; Malerba, E.; Fasano, R.; Buonavoglia, A.; Pappagallo, F.; De Re, V.; Argentiero, A.; Silvestris, N.; Vacca, A.; et al. Actors on the Scene: Immune Cells in the Myeloma Niche. Front. Oncol. 2020, 10, 599098. [CrossRef] [PubMed]

5. Munshi, N.C.; Avet-Loiseau, H.; Anderson, K.C.; Neri, P.; Paiva, B.; Samur, M.; Dimopoulos, M.; Kulakova, M.; Lam, A.; Hashim, M.; et al. A large meta-analysis establishes the role of MRD negativity in long-term survival outcomes in patients with multiple myeloma. Blood Adv. 2020, 4, 5988-5999. [CrossRef]

6. Pessoa de Magalhães, R.J.; Vidriales, M.B.; Paiva, B.; Fernandez-Gimenez, C.; García-Sanz, R.; Mateos, M.V.; Gutierrez, N.C.; Lecrevisse, Q.; Blanco, J.F.; Hernández, J.; et al. Analysis of the immune system of multiple myeloma patients achieving long-term disease control by multidimensional flow cytometry. Haematologica 2013, 98, 79-86. [CrossRef]

7. Facon, T.; Kumar, S.; Plesner, T.; Orlowski, R.Z.; Moreau, P.; Bahlis, N.; Basu, S.; Nahi, H.; Hulin, C.; Quach, H.; et al. Daratumumab plus Lenalidomide and Dexamethasone for Untreated Myeloma. N. Engl. J. Med. 2019, 380, 2104-2115. [CrossRef] [PubMed]

8. Dimopoulos, M.A.; Oriol, A.; Nahi, H.; San-Miguel, J.; Bahlis, N.J.; Usmani, S.Z.; Rabin, N.; Orlowski, R.Z.; Komarnicki, M.; Suzuki, K.; et al. Daratumumab, Lenalidomide, and Dexamethasone for Multiple Myeloma. N. Engl. J. Med. 2016, 375, 1319-1331. [CrossRef]

9. Lonial, S.; Dimopoulos, M.A.; Palumbo, A.; White, D.; Grosicki, S.; Spicka, I.; Walter-Croneck, A.; Moreau, P.; Mateos, M.V.; Magen, H.; et al. Elotuzumab Therapy for Relapsed or Refractory Multiple Myeloma. N. Engl. J. Med. 2015, 373, 621-631. [CrossRef] [PubMed]

10. Dimopoulos, M.A.; Dytfeld, D.; Grosicki, S.; Moreau, P.; Takezako, N.; Hori, M.; Leleu, X.; LeBlanc, R.; Suzuki, K.; Raab, M.S.; et al. Elotuzumab plus Pomalidomide and Dexamethasone for Multiple Myeloma. N. Engl. J. Med. 2018, 379, 1811-1822. [CrossRef]

11. Attal, M.; Richardson, P.G.; Rajkumar, S.V.; San-Miguel, J.; Beksac, M.; Spicka, I.; Leleu, X.; Schjesvold, F.; Moreau, P.; Dimopoulos, M.A.; et al. Isatuximab plus pomalidomide and low-dose dexamethasone versus pomalidomide and low-dose dexamethasone in patients with relapsed and refractory multiple myeloma (ICARIA-MM): A randomised, multicentre, open-label, phase 3 study. Lancet 2019, 394, 2096-2107. [CrossRef]

12. Jelinek, T.; Paiva, B.; Hajek, R. Update on PD-1/PD-L1 Inhibitors in Multiple Myeloma. Front. Immunol. 2018, 9, 2431. [CrossRef]

13. Voorhees, P.M.; Kaufman, J.L.; Laubach, J.; Sborov, D.W.; Reeves, B.; Rodriguez, C.; Chari, A.; Silbermann, R.; Costa, L.J.; Anderson, L.D., Jr.; et al. Daratumumab, lenalidomide, bortezomib, and dexamethasone for transplant-eligible newly diagnosed multiple myeloma: The GRIFFIN trial. Blood 2020, 136, 936-945. [CrossRef]

14. Attal, M.; Lauwers-Cances, V.; Hulin, C.; Leleu, X.; Caillot, D.; Escoffre, M.; Arnulf, B.; Macro, M.; Belhadj, K.; Garderet, L.; et al. Lenalidomide, Bortezomib, and Dexamethasone with Transplantation for Myeloma. N. Engl. J. Med. 2017, 376, 1311-1320. [CrossRef]

15. Jimenez-Zepeda, V.H.; Reece, D.E.; Trudel, S.; Chen, C.; Franke, N.; Winter, A.; Tiedemann, R.; Kukreti, V. Absolute lymphocyte count as predictor of overall survival for patients with multiple myeloma treated with single autologous stem cell transplant. Leuk. Lymphoma 2015, 56, 2668-2673. [CrossRef]

16. Diamond, B.; Korde, N.; Lesokhin, A.M.; Smith, E.L.; Shah, U.; Mailankody, S.; Hultcrantz, M.; Hassoun, H.; Lu, S.X.; Tan, C.; et al. Dynamics of minimal residual disease in patients with multiple myeloma on continuous lenalidomide maintenance: A single-arm, single-centre, phase 2 trial. Lancet Haematol. 2021, 8, e422-e432. [CrossRef] 
17. Balakumaran, A.; Robey, P.G.; Fedarko, N.; Landgren, O. Bone marrow microenvironment in myelomagenesis: Its potential role in early diagnosis. Expert Rev. Mol. Diagn. 2010, 10, 465-480. [CrossRef]

18. Papadimitriou, K.; Tsakirakis, N.; Malandrakis, P.; Vitsos, P.; Metousis, A.; Orologas-Stavrou, N.; Ntanasis-Stathopoulos, I.; Kanellias, N.; Eleutherakis-Papaiakovou, E.; Pothos, P.; et al. Deep Phenotyping Reveals Distinct Immune Signatures Correlating with Prognostication, Treatment Responses, and MRD Status in Multiple Myeloma. Cancers 2020, 12, 3245. [CrossRef] [PubMed]

19. Farhood, B.; Najafi, M.; Mortezaee, K. CD8 ${ }^{+}$cytotoxic T lymphocytes in cancer immunotherapy: A review. J. Cell. Physiol. 2019, 234, 8509-8521. [CrossRef] [PubMed]

20. Kennedy, R.; Celis, E. Multiple roles for CD4+ T cells in anti-tumor immune responses. Immunol. Rev. 2008, 222, 129-144. [CrossRef] [PubMed]

21. Pratt, G.; Goodyear, O.; Moss, P. Immunodeficiency and immunotherapy in multiple myeloma. Br. J. Haematol. 2007, 138, 563-579. [CrossRef] [PubMed]

22. Zelle-Rieser, C.; Thangavadivel, S.; Biedermann, R.; Brunner, A.; Stoitzner, P.; Willenbacher, E.; Greil, R.; Jöhrer, K. T cells in multiple myeloma display features of exhaustion and senescence at the tumor site. J. Hematol. Oncol. 2016, 9, 116. [CrossRef] [PubMed]

23. Kay, N.E.; Leong, T.L.; Bone, N.; Vesole, D.H.; Greipp, P.R.; Van Ness, B.; Oken, M.M.; Kyle, R.A. Blood levels of immune cells predict survival in myeloma patients: Results of an Eastern Cooperative Oncology Group phase 3 trial for newly diagnosed multiple myeloma patients. Blood 2001, 98, 23-28. [CrossRef]

24. Suen, H.; Brown, R.; Yang, S.; Weatherburn, C.; Ho, P.J.; Woodland, N.; Nassif, N.; Barbaro, P.; Bryant, C.; Hart, D.; et al. Multiple myeloma causes clonal T-cell immunosenescence: Identification of potential novel targets for promoting tumour immunity and implications for checkpoint blockade. Leukemia 2016, 30, 1716-1724. [CrossRef]

25. Dhodapkar, M.V.; Krasovsky, J.; Osman, K.; Geller, M.D. Vigorous premalignancy-specific effector T cell response in the bone marrow of patients with monoclonal gammopathy. J. Exp. Med. 2003, 198, 1753-1757. [CrossRef]

26. Crespo, J.; Sun, H.; Welling, T.H.; Tian, Z.; Zou, W. T cell anergy, exhaustion, senescence, and stemness in the tumor microenvironment. Curr. Opin. Immunol. 2013, 25, 214-221. [CrossRef]

27. An, G.; Acharya, C.; Feng, X.; Wen, K.; Zhong, M.; Zhang, L.; Munshi, N.C.; Qiu, L.; Tai, Y.T.; Anderson, K.C. Osteoclasts promote immune suppressive microenvironment in multiple myeloma: Therapeutic implication. Blood 2016, 128, 1590-1603. [CrossRef]

28. Wang, L.; Wang, H.; Chen, H.; Wang, W.D.; Chen, X.Q.; Geng, Q.R.; Xia, Z.J.; Lu, Y. Serum levels of soluble programmed death ligand 1 predict treatment response and progression free survival in multiple myeloma. Oncotarget 2015, 6, 41228-41236. [CrossRef]

29. Schwartz, R.H. T cell anergy. Annu. Rev. Immunol. 2003, 21, 305-334. [CrossRef] [PubMed]

30. Choi, S.; Schwartz, R.H. Molecular mechanisms for adaptive tolerance and other T cell anergy models. Semin. Immunol. 2007, 19, 140-152. [CrossRef] [PubMed]

31. Ahmadzadeh, M.; Johnson, L.A.; Heemskerk, B.; Wunderlich, J.R.; Dudley, M.E.; White, D.E.; Rosenberg, S.A. Tumor antigenspecific CD8 T cells infiltrating the tumor express high levels of PD-1 and are functionally impaired. Blood 2009, 114, 1537-1544. [CrossRef]

32. Chevrier, S.; Levine, J.H.; Zanotelli, V.R.T.; Silina, K.; Schulz, D.; Bacac, M.; Ries, C.H.; Ailles, L.; Jewett, M.A.S.; Moch, H.; et al. An Immune Atlas of Clear Cell Renal Cell Carcinoma. Cell 2017, 169, 736-749.e18. [CrossRef] [PubMed]

33. Chen, L.; Diao, L.; Yang, Y.; Yi, X.; Rodriguez, B.L.; Li, Y.; Villalobos, P.A.; Cascone, T.; Liu, X.; Tan, L.; et al. CD38-Mediated Immunosuppression as a Mechanism of Tumor Cell Escape from PD-1/PD-L1 Blockade. Cancer Discov. 2018, 8, 1156-1175. [CrossRef] [PubMed]

34. Vivier, E.; Tomasello, E.; Baratin, M.; Walzer, T.; Ugolini, S. Functions of natural killer cells. Nat. Immunol. 2008, 9, 503-510. [CrossRef] [PubMed]

35. Dosani, T.; Carlsten, M.; Maric, I.; Landgren, O. The cellular immune system in myelomagenesis: NK cells and T cells in the development of myeloma and their uses in immunotherapies. Blood Cancer J. 2015, 5, e306. [CrossRef] [PubMed]

36. Mellor, J.D.; Brown, M.P.; Irving, H.R.; Zalcberg, J.R.; Dobrovic, A. A critical review of the role of Fc gamma receptor polymorphisms in the response to monoclonal antibodies in cancer. J. Hematol. Oncol. 2013, 6, 1. [CrossRef]

37. El-Sherbiny, Y.M.; Meade, J.L.; Holmes, T.D.; McGonagle, D.; Mackie, S.L.; Morgan, A.W.; Cook, G.; Feyler, S.; Richards, S.J.; Davies, F.E.; et al. The requirement for DNAM-1, NKG2D, and NKp46 in the natural killer cell-mediated killing of myeloma cells. Cancer Res. 2007, 67, 8444-8449. [CrossRef] [PubMed]

38. Muntasell, A.; Magri, G.; Pende, D.; Angulo, A.; López-Botet, M. Inhibition of NKG2D expression in NK cells by cytokines secreted in response to human cytomegalovirus infection. Blood 2010, 115, 5170-5179. [CrossRef]

39. Benson, D.M., Jr.; Bakan, C.E.; Mishra, A.; Hofmeister, C.C.; Efebera, Y.; Becknell, B.; Baiocchi, R.A.; Zhang, J.; Yu, J.; Smith, M.K.; et al. The PD-1/PD-L1 axis modulates the natural killer cell versus multiple myeloma effect: A therapeutic target for CT-011, a novel monoclonal anti-PD-1 antibody. Blood 2010, 116, 2286-2294. [CrossRef]

40. Raffin, C.; Vo, L.T.; Bluestone, J.A. Treg cell-based therapies: Challenges and perspectives. Nat. Rev. Immunol. 2020, 20, 158-172. [CrossRef]

41. Sakaguchi, S.; Wing, K.; Onishi, Y.; Prieto-Martin, P.; Yamaguchi, T. T Regulatory T cells: How do they suppress immune responses? Int. Immunol. 2009, 21, 1105-1111. [CrossRef] [PubMed] 
42. Onishi, Y.; Fehervari, Z.; Yamaguchi, T.; Sakaguchi, S. Foxp3 ${ }^{+}$natural regulatory T cells preferentially form aggregates on dendritic cells in vitro and actively inhibit their maturation. Proc. Natl. Acad. Sci. USA 2008, 105, 10113-10118. [CrossRef]

43. Muthu Raja, K.R.; Rihova, L.; Zahradova, L.; Klincova, M.; Penka, M.; Hajek, R. Increased T regulatory cells are associated with adverse clinical features and predict progression in multiple myeloma. PLoS ONE 2012, 7, e47077. [CrossRef] [PubMed]

44. Feyler, S.; von Lilienfeld-Toal, M.; Jarmin, S.; Marles, L.; Rawstron, A.; Ashcroft, A.J.; Owen, R.G.; Selby, P.J.; Cook, G. CD4(+)CD25(+)FoxP3(+) regulatory T cells are increased whilst CD3(+)CD4(-)CD8(-)alphabetaTCR(+) Double Negative T cells are decreased in the peripheral blood of patients with multiple myeloma which correlates with disease burden. Br. J. Haematol. 2009, 144, 686-695. [CrossRef] [PubMed]

45. Giannopoulos, K.; Kaminska, W.; Hus, I.; Dmoszynska, A. The frequency of T regulatory cells modulates the survival of multiple myeloma patients: Detailed characterisation of immune status in multiple myeloma. Br. J. Cancer 2012, 106, 546-552. [CrossRef]

46. Feyler, S.; Scott, G.B.; Parrish, C.; Jarmin, S.; Evans, P.; Short, M.; McKinley, K.; Selby, P.J.; Cook, G. Tumour cell generation of inducible regulatory T-cells in multiple myeloma is contact-dependent and antigen-presenting cell-independent. PLoS ONE 2012, 7, e35981. [CrossRef]

47. Rawstron, A.C.; Davies, F.E.; Owen, R.G.; English, A.; Pratt, G.; Child, J.A.; Jack, A.S.; Morgan, G.J. B-lymphocyte suppression in multiple myeloma is a reversible phenomenon specific to normal B-cell progenitors and plasma cell precursors. Br. J. Haematol. 1998, 100, 176-183. [CrossRef]

48. Urashima, M.; Ogata, A.; Chauhan, D.; Hatziyanni, M.; Vidriales, M.B.; Dedera, D.A.; Schlossman, R.L.; Anderson, K.C. Transforming growth factor-beta1: Differential effects on multiple myeloma versus normal B cells. Blood 1996, 87, 1928-1938. [CrossRef]

49. Rosser, E.C.; Mauri, C. Regulatory B cells: Origin, phenotype, and function. Immunity 2015, 42, 607-612. [CrossRef]

50. Zhang, L.; Tai, Y.T.; Ho, M.; Xing, L.; Chauhan, D.; Gang, A.; Qiu, L.; Anderson, K.C. Regulatory B cell-myeloma cell interaction confers immunosuppression and promotes their survival in the bone marrow milieu. Blood Cancer J. 2017, 7, e547. [CrossRef]

51. Bakema, J.E.; van Egmond, M. Fc receptor-dependent mechanisms of monoclonal antibody therapy of cancer. Curr. Top. Microbiol. Immunol. 2014, 382, 373-392. [CrossRef] [PubMed]

52. Pollard, J.W. Tumour-educated macrophages promote tumour progression and metastasis. Nat. Rev. Cancer. 2004, 4, 71-78. [CrossRef] [PubMed]

53. Scavelli, C.; Nico, B.; Cirulli, T.; Ria, R.; Di Pietro, G.; Mangieri, D.; Bacigalupo, A.; Mangialardi, G.; Coluccia, A.M.; Caravita, T.; et al. Vasculogenic mimicry by bone marrow macrophages in patients with multiple myeloma. Oncogene 2008, 27, 663-674. [CrossRef] [PubMed]

54. Ben-Baruch, A. Inflammation-associated immune suppression in cancer: The roles played by cytokines, chemokines and additional mediators. Semin. Cancer Biol. 2006, 16, 38-52. [CrossRef] [PubMed]

55. Zheng, Y.; Cai, Z.; Wang, S.; Zhang, X.; Qian, J.; Hong, S.; Li, H.; Wang, M.; Yang, J.; Yi, Q. Macrophages are an abundant component of myeloma microenvironment and protect myeloma cells from chemotherapy drug-induced apoptosis. Blood 2009, 114, 3625-3628. [CrossRef]

56. Quach, H.; Ritchie, D.; Stewart, A.K.; Neeson, P.; Harrison, S.; Smyth, M.J.; Prince, H.M. Mechanism of action of immunomodulatory drugs (IMiDS) in multiple myeloma. Leukemia 2010, 24, 22-32. [CrossRef]

57. Lopez-Girona, A.; Mendy, D.; Ito, T.; Miller, K.; Gandhi, A.K.; Kang, J.; Karasawa, S.; Carmel, G.; Jackson, P.; Abbasian, M.; et al. Cereblon is a direct protein target for immunomodulatory and antiproliferative activities of lenalidomide and pomalidomide. Leukemia 2012, 26, 2326-2335. [CrossRef]

58. Dredge, K.; Marriott, J.B.; Todryk, S.M.; Muller, G.W.; Chen, R.; Stirling, D.I.; Dalgleish, A.G. Protective antitumor immunity induced by a costimulatory thalidomide analog in conjunction with whole tumor cell vaccination is mediated by increased Th1-type immunity. J. Immunol. 2002, 168, 4914-4919. [CrossRef]

59. Hayashi, T.; Hideshima, T.; Akiyama, M.; Podar, K.; Yasui, H.; Raje, N.; Kumar, S.; Chauhan, D.; Treon, S.P.; Richardson, P.G.; et al. Molecular mechanisms whereby immunomodulatory drugs activate natural killer cells: Clinical application. Br. J. Haematol. 2005, 128, 192-203. [CrossRef]

60. Wu, L.; Adams, M.; Carter, T.; Chen, R.; Muller, G.; Stirling, D.; Schafer, P.; Bartlett, J.B. Lenalidomide enhances natural killer cell and monocyte-mediated antibody-dependent cellular cytotoxicity of rituximab-treated CD20+ tumor cells. Clin. Cancer Res. 2008, 14, 4650-4657. [CrossRef]

61. Mougiakakos, D.; Bach, C.; Böttcher, M.; Beier, F.; Röhner, L.; Stoll, A.; Rehli, M.; Gebhard, C.; Lischer, C.; Eberhardt, M.; et al. The IKZF1-IRF4/IRF5 Axis Controls Polarization of Myeloma-Associated Macrophages. Cancer Immunol. Res. 2021, 9, 265-278. [CrossRef] [PubMed]

62. Krejcik, J.; Casneuf, T.; Nijhof, I.S.; Verbist, B.; Bald, J.; Plesner, T.; Syed, K.; Liu, K.; van de Donk, N.W.; Weiss, B.M.; et al. Daratumumab depletes CD38+ immune regulatory cells, promotes T-cell expansion, and skews T-cell repertoire in multiple myeloma. Blood 2016, 128, 384-394. [CrossRef] [PubMed]

63. de Weers, M.; Tai, Y.T.; van der Veer, M.S.; Bakker, J.M.; Vink, T.; Jacobs, D.C.; Oomen, L.A.; Peipp, M.; Valerius, T.; Slootstra, J.W.; et al. Daratumumab, a novel therapeutic human CD38 monoclonal antibody, induces killing of multiple myeloma and other hematological tumors. J. Immunol. 2011, 186, 1840-1848. [CrossRef] 
64. Casneuf, T.; Xu, X.S.; Adams, H.C., 3rd; Axel, A.E.; Chiu, C.; Khan, I.; Ahmadi, T.; Yan, X.; Lonial, S.; Plesner, T.; et al. Effects of daratumumab on natural killer cells and impact on clinical outcomes in relapsed or refractory multiple myeloma. Blood Adv. 2017, 1, 2105-2114. [CrossRef]

65. Wang, Y.; Zhang, Y.; Hughes, T.; Zhang, J.; Caligiuri, M.A.; Benson, D.M.; Yu, J. Fratricide of NK Cells in Daratumumab Therapy for Multiple Myeloma Overcome by Ex Vivo-Expanded Autologous NK Cells. Clin. Cancer Res. 2018, 24, 4006-4017. [CrossRef]

66. Chillemi, A.; Quarona, V.; Antonioli, L.; Ferrari, D.; Horenstein, A.L.; Malavasi, F. Roles and Modalities of Ectonucleotidases in Remodeling the Multiple Myeloma Niche. Front. Immunol. 2017, 8, 305. [CrossRef]

67. Morandi, F.; Morandi, B.; Horenstein, A.L.; Chillemi, A.; Quarona, V.; Zaccarello, G.; Carrega, P.; Ferlazzo, G.; Mingari, M.C.; Moretta, L.; et al. A non-canonical adenosinergic pathway led by CD38 in human melanoma cells induces suppression of T cell proliferation. Oncotarget 2015, 6, 25602-25618. [CrossRef]

68. Morandi, F.; Horenstein, A.L.; Chillemi, A.; Quarona, V.; Chiesa, S.; Imperatori, A.; Zanellato, S.; Mortara, L.; Gattorno, M.; Pistoia, V.; et al. CD56brightCD16- NK Cells Produce Adenosine through a CD38-Mediated Pathway and Act as Regulatory Cells Inhibiting Autologous CD4+ T Cell Proliferation. J. Immunol. 2015, 195, 965-972. [CrossRef]

69. Overdijk, M.B.; Verploegen, S.; Bögels, M.; van Egmond, M.; Lammerts van Bueren, J.J.; Mutis, T.; Groen, R.W.; Breij, E.; Martens, A.C.; Bleeker, W.K.; et al. Antibody-mediated phagocytosis contributes to the anti-tumor activity of the therapeutic antibody daratumumab in lymphoma and multiple myeloma. MAbs 2015, 7, 311-321. [CrossRef]

70. Montes De Oca, R.; Bhattacharya, S.; Vitali, N.; Patel, K.; Kaczynski, H.; Shi, H.Z.; Blackwell, C.; Seestaller-Wehr, L.; Cooper, D.; Jackson, H.; et al. The anti-BCMA antibody-drug conjugate GSK857916 drives immunogenic cell death and immune mediated antitumor responses, and in combination with an Ox40 agonist potentiates in vivo activity. HemaSphere 2019, 3, 231. [CrossRef]

71. Condomines, M.; Veyrune, J.L.; Larroque, M.; Quittet, P.; Latry, P.; Lugagne, C.; Hertogh, C.; Kanouni, T.; Rossi, J.F.; Klein, B. Increased plasma-immune cytokines throughout the high-dose melphalan-induced lymphodepletion in patients with multiple myeloma: A window for adoptive immunotherapy. J. Immunol. 2010, 184, 1079-1084. [CrossRef]

72. Lu, X.; Ding, Z.C.; Cao, Y.; Liu, C.; Habtetsion, T.; Yu, M.; Lemos, H.; Salman, H.; Xu, H.; Mellor, A.L.; et al. Alkylating agent melphalan augments the efficacy of adoptive immunotherapy using tumor-specific CD4+ T cells. J. Immunol. 2015, 194, $2011-2021$. [CrossRef]

73. Görgün, G.T.; Whitehill, G.; Anderson, J.L.; Hideshima, T.; Maguire, C.; Laubach, J.; Raje, N.; Munshi, N.C.; Richardson, P.G.; Anderson, K.C. Tumor-promoting immune-suppressive myeloid-derived suppressor cells in the multiple myeloma microenvironment in humans. Blood 2013, 121, 2975-2987. [CrossRef] [PubMed]

74. Shi, J.; Tricot, G.J.; Garg, T.K.; Malaviarachchi, P.A.; Szmania, S.M.; Kellum, R.E.; Storrie, B.; Mulder, A.; Shaughnessy, J.D., Jr.; Barlogie, B.; et al. Bortezomib down-regulates the cell-surface expression of HLA class I and enhances natural killer cell-mediated lysis of myeloma. Blood 2008, 111, 1309-1317. [CrossRef] [PubMed]

75. Thangaraj, J.L.; Ahn, S.Y.; Jung, S.H.; Vo, M.C.; Chu, T.H.; Thi Phan, M.T.; Kwon, M.; Lee, K.H.; Kim, M.; Song, G.Y.; et al. Expanded natural killer cells augment the antimyeloma effect of daratumumab, bortezomib, and dexamethasone in a mouse model. Cell. Mol. Immunol. 2021, 18, 1652-1661. [CrossRef] [PubMed]

76. Binder, M.; Rajkumar, S.V.; Lacy, M.Q.; Gertz, M.A.; Buadi, F.K.; Dispenzieri, A.; Hwa, Y.L.; Fonder, A.; Hobbs, M.; Hayman, S.R.; et al. Peripheral blood biomarkers of early immune reconstitution in newly diagnosed multiple myeloma. Am. J. Hematol. 2019, 94, 306-311. [CrossRef]

77. San Miguel, J.F.; González, M.; Gascón, A.; Moro, M.J.; Hernández, J.M.; Ortega, F.; Jiménez, R.; Guerras, L.; Romero, M.; Casanova, F; et al. Lymphoid subsets and prognostic factors in multiple myeloma. Cooperative Group for the Study of Monoclonal Gammopathies. Br. J. Haematol. 1992, 80, 305-309. [CrossRef]

78. Brown, R.D.; Yuen, E.; Nelson, M.; Gibson, J.; Joshua, D. The prognostic significance of T cell receptor beta gene rearrangements and idiotype-reactive T cells in multiple myeloma. Leukemia 1997, 11, 1312-1317. [CrossRef]

79. Bryant, C.; Suen, H.; Brown, R.; Yang, S.; Favaloro, J.; Aklilu, E.; Gibson, J.; Ho, P.J.; Iland, H.; Fromm, P.; et al. Long-term survival in multiple myeloma is associated with a distinct immunological profile, which includes proliferative cytotoxic T-cell clones and a favourable Treg/Th17 balance. Blood Cancer J. 2013, 3, e148. [CrossRef]

80. Arteche-López, A.; Kreutzman, A.; Alegre, A.; Sanz Martín, P.; Aguado, B.; González-Pardo, M.; Espiño, M.; Villar, L.M.; García Belmonte, D.; de la Cámara, R.; et al. Multiple myeloma patients in long-term complete response after autologous stem cell transplantation express a particular immune signature with potential prognostic implication. Bone Marrow Transplant. 2017, 52, 832-838. [CrossRef]

81. Parmar, H.; Gertz, M.; Anderson, E.I.; Kumar, S.; Kourelis, T.V. Microenvironment immune reconstitution patterns correlate with outcomes after autologous transplant in multiple myeloma. Blood Adv. 2021, 5, 1797-1804. [CrossRef]

82. Paiva, B.; Cedena, M.T.; Puig, N.; Arana, P.; Vidriales, M.B.; Cordon, L.; Flores-Montero, J.; Gutierrez, N.C.; Martín-Ramos, M.L.; Martinez-Lopez, J.; et al. Minimal residual disease monitoring and immune profiling in multiple myeloma in elderly patients. Blood 2016, 127, 3165-3174. [CrossRef] [PubMed]

83. Heaney, J.L.J.; Campbell, J.P.; Iqbal, G.; Cairns, D.; Richter, A.; Child, J.A.; Gregory, W.; Jackson, G.; Kaiser, M.; Owen, R.; et al. Characterisation of immunoparesis in newly diagnosed myeloma and its impact on progression-free and overall survival in both old and recent myeloma trials. Leukemia 2018, 32, 1727-1738. [CrossRef] [PubMed]

84. Pruzanski, W.; Gidon, M.S.; Roy, A. Suppression of polyclonal immunoglobulins in multiple myeloma: Relationship to the staging and other manifestations at diagnosis. Clin. Immunol. Immunopathol. 1980, 17, 280-286. [CrossRef] 
85. Wang, L.; Young, D.C. Suppression of polyclonal immunoglobulin production by M-proteins shows isotype specificity. Ann. Clin. Lab. Sci. 2001, 31, 274-278.

86. De Larrea, C.F.; Cibeira, M.T.; Elena, M.; Arostegui, J.I.; Rosiñol, L.; Rovira, M.; Filella, X.; Yagüe, J.; Bladé, J. Abnormal serum free light chain ratio in patients with multiple myeloma in complete remission has strong association with the presence of oligoclonal bands: Implications for stringent complete remission definition. Blood 2009, 114, 4954-4956. [CrossRef] [PubMed]

87. Zent, C.S.; Wilson, C.S.; Tricot, G.; Jagannath, S.; Siegel, D.; Desikan, K.R.; Munshi, N.; Bracy, D.; Barlogie, B.; Butch, A.W. Oligoclonal protein bands and Ig isotype switching in multiple myeloma treated with high-dose therapy and hematopoietic cell transplantation. Blood 1998, 91, 3518-3523. [CrossRef]

88. Bladé, J.; Fernández de Larrea, C.; Rosiñol, L.; Cibeira, M.T.; Jiménez, R.; Powles, R. Soft-tissue plasmacytomas in multiple myeloma: Incidence, mechanisms of extramedullary spread, and treatment approach. J. Clin. Oncol. 2011, 29, 3805-3812. [CrossRef]

89. Ye, R.; Kundrapu, S.; Gerson, S.L.; Driscoll, J.J.; Beck, R.; Ali, N.; Landgren, O.; Van Heeckeren, W.; Luo, G.; Kroger, N.; et al. Immune Signatures Associated With Clonal Isotype Switch After Autologous Stem Cell Transplantation for Multiple Myeloma. Clin. Lymphoma Myeloma Leuk. 2019, 19, e213-e220. [CrossRef]

90. Jo, J.C.; Yoon, D.H.; Kim, S.; Lee, K.; Kang, E.H.; Jang, S.; Park, C.J.; Chi, H.S.; Huh, J.; Park, C.S.; et al. Clinical significance of the appearance of abnormal protein band in patients with multiple myeloma. Ann. Hematol. 2014, 93, 463-469. [CrossRef]

91. Jimenez-Zepeda, V.H.; Reece, D.E.; Trudel, S.; Franke, N.; Winter, A.; Chen, C.; Tiedemann, R.; Kukreti, V. Oligoclonal and monoclonal bands after single autologous stem cell transplant in patients with multiple myeloma: Impact on overall survival and progression-free survival. Leuk. Lymphoma 2014, 55, 2284-2289. [CrossRef]

92. Kourelis, T.V.; Villasboas, J.C.; Jessen, E.; Dasari, S.; Dispenzieri, A.; Jevremovic, D.; Kumar, S. Mass cytometry dissects T cell heterogeneity in the immune tumor microenvironment of common dysproteinemias at diagnosis and after first line therapies. Blood Cancer J. 2019, 9, 72. [CrossRef]

93. Galustian, C.; Meyer, B.; Labarthe, M.C.; Dredge, K.; Klaschka, D.; Henry, J.; Todryk, S.; Chen, R.; Muller, G.; Stirling, D.; et al. The anti-cancer agents lenalidomide and pomalidomide inhibit the proliferation and function of T regulatory cells. Cancer Immunol. Immunother. 2009, 58, 1033-1045. [CrossRef] [PubMed]

94. Bjorklund, C.C.; Lu, L.; Kang, J.; Hagner, P.R.; Havens, C.G.; Amatangelo, M.; Wang, M.; Ren, Y.; Couto, S.; Breider, M.; et al. Rate of CRL4(CRBN) substrate Ikaros and Aiolos degradation underlies differential activity of lenalidomide and pomalidomide in multiple myeloma cells by regulation of c-Myc and IRF4. Blood Cancer J. 2015, 5, e354. [CrossRef]

95. Bjorklund, C.C.; Kang, J.; Amatangelo, M.; Polonskaia, A.; Katz, M.; Chiu, H.; Couto, S.; Wang, M.; Ren, Y.; Ortiz, M.; et al. Iberdomide (CC-220) is a potent cereblon E3 ligase modulator with antitumor and immunostimulatory activities in lenalidomideand pomalidomide-resistant multiple myeloma cells with dysregulated CRBN. Leukemia 2020, 34, 1197-1201. [CrossRef] [PubMed]

96. Van De Donk, N.W.C.J.; Popat, R.; Larsen, J.; Minnema, M.C.; Jagannath, S.; Oriol, A.; Zonder, J.; Richardson, P.G.; Rodriguez-Otero, P.; Bardros, A.Z.; et al. First Results of Iberdomide (IBER; CC-220) in Combination with Dexamethasone (DEX) and Daratumumab (DARA) or Bortezomib (BORT) in Patients with Relapsed/Refractory Multiple Myeloma (RRMM). Blood 2020, 136 (Suppl. 1), 16-17. [CrossRef]

97. Casneuf, T.; Adams, H.C., 3rd; van de Donk, N.W.C.J.; Abraham, Y.; Bald, J.; Vanhoof, G.; Van der Borght, K.; Smets, T.; Foulk, B.; Nielsen, K.C.; et al. Deep immune profiling of patients treated with lenalidomide and dexamethasone with or without daratumumab. Leukemia 2021, 35, 573-584. [CrossRef] [PubMed]

98. Jiang, H.; Acharya, C.; An, G.; Zhong, M.; Feng, X.; Wang, L.; Dasilva, N.; Song, Z.; Yang, G.; Adrian, F.; et al. SAR650984 directly induces multiple myeloma cell death via lysosomal-associated and apoptotic pathways, which is further enhanced by pomalidomide. Leukemia 2016, 30, 399-408. [CrossRef]

99. Moreno, L.; Perez, C.; Zabaleta, A.; Manrique, I.; Alignani, D.; Ajona, D.; Blanco, L.; Lasa, M.; Maiso, P.; Rodriguez, I.; et al. The Mechanism of Action of the Anti-CD38 Monoclonal Antibody Isatuximab in Multiple Myeloma. Clin. Cancer Res. 2019, 25, 3176-3187. [CrossRef]

100. Usmani, S.Z.; Schjesvold, F.; Oriol, A.; Karlin, L.; Cavo, M.; Rifkin, R.M.; Yimer, H.A.; LeBlanc, R.; Takezako, N.; McCroskey, R.D.; et al. Pembrolizumab plus lenalidomide and dexamethasone for patients with treatment-naive multiple myeloma (KEYNOTE-185): A randomised, open-label, phase 3 trial. Lancet Haematol. 2019, 6, e448-e458. [CrossRef]

101. Frerichs, K.A.; Verkleij, C.P.M.; Dimopoulos, M.A.; Marin Soto, J.A.; Zweegman, S.; Young, M.H.; Newhall, K.J.; Mutis, T.; van de Donk, N.W.C.J. Efficacy and Safety of Durvalumab Combined with Daratumumab in Daratumumab-Refractory Multiple Myeloma Patients. Cancers 2021, 13, 2452. [CrossRef]

102. Tai, Y.T.; Mayes, P.A.; Acharya, C.; Zhong, M.Y.; Cea, M.; Cagnetta, A.; Craigen, J.; Yates, J.; Gliddon, L.; Fieles, W.; et al. Novel anti-B-cell maturation antigen antibody-drug conjugate (GSK2857916) selectively induces killing of multiple myeloma. Blood 2014, 123, 3128-3138. [CrossRef]

103. Storek, J.; Dawson, M.A.; Storer, B.; Stevens-Ayers, T.; Maloney, D.G.; Marr, K.A.; Witherspoon, R.P.; Bensinger, W.; Flowers, M.E.; Martin, P.; et al. Immune reconstitution after allogeneic marrow transplantation compared with blood stem cell transplantation. Blood 2001, 97, 3380-3389. [CrossRef]

104. Spisek, R.; Charalambous, A.; Mazumder, A.; Vesole, D.H.; Jagannath, S.; Dhodapkar, M.V. Bortezomib enhances dendritic cell (DC)-mediated induction of immunity to human myeloma via exposure of cell surface heat shock protein 90 on dying tumor cells: Therapeutic implications. Blood 2007, 109, 4839-4845. [CrossRef] [PubMed] 
105. Gulla, A.; Morelli, E.; Samur, M.K.; Botta, C.; Hideshima, T.; Bianchi, G.; Fulciniti, M.; Malvestiti, S.; Srikanth Talluri, R.P.; Tai, Y.T.; et al. Bortezomib induces anti-multiple myeloma immune response mediated by cgas/sting pathway activation, type I interferon secretion, and immunogenic cell death: Clinical application. Blood 2020, 136, 7-8. [CrossRef]

106. Kumar, S.; Paiva, B.; Anderson, K.C.; Durie, B.; Landgren, O.; Moreau, P.; Munshi, N.; Lonial, S.; Bladé, J.; Mateos, M.V.; et al. International Myeloma Working Group consensus criteria for response and minimal residual disease assessment in multiple myeloma. Lancet Oncol. 2016, 17, e328-e346. [CrossRef]

107. Paiva, B.; Puig, N.; Cedena, M.T.; Rosiñol, L.; Cordón, L.; Vidriales, M.B.; Burgos, L.; Flores-Montero, J.; Sanoja-Flores, L.; Lopez-Anglada, L.; et al. Measurable Residual Disease by Next-Generation Flow Cytometry in Multiple Myeloma. J. Clin. Oncol. 2020, 38, 784-792. [CrossRef] [PubMed]

108. Perrot, A.; Lauwers-Cances, V.; Corre, J.; Robillard, N.; Hulin, C.; Chretien, M.L.; Dejoie, T.; Maheo, S.; Stoppa, A.M.; Pegourie, B.; et al. Minimal residual disease negativity using deep sequencing is a major prognostic factor in multiple myeloma. Blood 2018, 132, 2456-2464. [CrossRef]

109. Oliva, S.; Bruinink, D.H.O.; Rihova, L.; D’Agostino, M.; Pantani, L.; Capra, A.; van der Holt, B.; Troia, R.; Petrucci, M.T.; Villanova, T.; et al. Minimal residual disease assessment by multiparameter flow cytometry in transplant-eligible myeloma in the EMN02/HOVON 95 MM trial. Blood Cancer J. 2021, 11, 106. [CrossRef] [PubMed]

110. Hahn, T.E.; Wallace, P.K.; Fraser, R.; Fei, M.; Tario, J.D.; Howard, A.; Zhang, Y.; Blackwell, B.; Brunstein, C.G.; Efebera, Y.A.; et al. Minimal Residual Disease (MRD) Assessment before and after Autologous Hematopoietic Cell Transplantation (AutoHCT) and Maintenance for Multiple Myeloma (MM): Results of the Prognostic Immunophenotyping for Myeloma Response (PRIMeR) Study. Biol. Blood Marrow Transplant. 2019, 25, S4-S6. [CrossRef]

111. Oliva, S.; Genuardi, E.; Belotti, A.; Frascione, P.M.M.; Galli, M.; Capra, A.; Offidani, M.; Vozella, F.; Zambello, R.; Auclair, D.; et al. Multiparameter flow cytometry (MFC) and next generation sequencing (NGS) for minimal residual disease (MRD) evaluation: Results of the FORTE trial in newly diagnosed multiple myeloma (MM). J. Clin. Oncol. 2020, 38, 8533. [CrossRef]

112. Moreau, P.; Attal, M.; Hulin, C.; Arnulf, B.; Belhadj, K.; Benboubker, L.; Béné, M.C.; Broijl, A.; Caillon, H.; Caillot, D.; et al. Bortezomib, thalidomide, and dexamethasone with or without daratumumab before and after autologous stem-cell transplantation for newly diagnosed multiple myeloma (CASSIOPEIA): A randomised, open-label, phase 3 study. Lancet 2019, 394, 29-38. [CrossRef]

113. Moreau, P.; Hulin, C.; Perrot, A.; Arnulf, B.; Belhadj, K.; Benboubker, L.; Bene, M.C.; Zweegman, S.; Caillon, H.; Caillot, D.; et al. Maintenance with daratumumab or observation following treatment with bortezomib, thalidomide, and dexamethasone with or without daratumumab and autologous stem-cell transplantation in patients with newly diagnosed multiple myeloma (CASSIOPEIA): An open-label, randomized, phase 3 trial. Lancet Oncol. 2021, 22, 1378-1390. [CrossRef]

114. Mateos, M.V.; Cavo, M.; Blade, J.; Dimopoulos, M.A.; Suzuki, K.; Jakubowiak, A.; Knop, S.; Doyen, C.; Lucio, P.; Nagy, Z.; et al. Overall survival with daratumumab, bortezomib, melphalan, and prednisone in newly diagnosed multiple myeloma (ALCYONE): A randomised, open-label, phase 3 trial. Lancet 2020, 395, 132-141. [CrossRef]

115. Avet-Loiseau, H.; San-Miguel, J.; Casneuf, T.; Iida, S.; Lonial, S.; Usmani, S.Z.; Spencer, A.; Moreau, P.; Plesner, T.; Weisel, K.; et al. Evaluation of Sustained Minimal Residual Disease Negativity with Daratumumab- Combination Regimens in Relapsed and/or Refractory Multiple Myeloma: Analysis of POLLUX and CASTOR. J. Clin. Oncol. 2021, 39, 1139-1149. [CrossRef] [PubMed]

116. Dimopoulos, M.; Quach, H.; Mateos, M.V.; Landgren, O.; Leleu, X.; Siegel, D.; Weisel, K.; Yang, H.; Klippel, Z.; Zahlten-Kumeli, A.; et al. Carfilzomib, dexamethasone, and daratumumab versus carfilzomib and dexamethasone for patients with relapsed or refractory multiple myeloma (CANDOR): Results from a randomised, multicentre, open-label, phase 3 study. Lancet 2020, 396, 186-197. [CrossRef]

117. Bertamini, L.; D’Agostino, M.; Gay, F. MRD Assessment in Multiple Myeloma: Progress and Challenges. Curr. Hematol. Malig. Rep. 2021, 16, 162-171. [CrossRef]

118. Bal, S.; Giri, S.; Godby, K.N.; Costa, L.J. New regimens and directions in the management of newly diagnosed multiple myeloma. Am. J. Hematol. 2021, 96, 367-378. [CrossRef] [PubMed]

119. Sanoja-Flores, L.; Flores-Montero, J.; Puig, N.; Contreras-Sanfeliciano, T.; Pontes, R.; Corral-Mateos, A.; García-Sánchez, O.; Díez-Campelo, M.; Pessoa de Magalhães, R.J.; García-Martín, L.; et al. Blood monitoring of circulating tumor plasma cells by next generation flow in multiple myeloma after therapy. Blood 2019, 134, 2218-2222. [CrossRef]

120. Mazzotti, C.; Buisson, L.; Maheo, S.; Perrot, A.; Chretien, M.L.; Leleu, X.; Hulin, C.; Manier, S.; Hébraud, B.; Roussel, M.; et al. Myeloma MRD by deep sequencing from circulating tumor DNA does not correlate with results obtained in the bone marrow. Blood Adv. 2018, 2, 2811-2813. [CrossRef] [PubMed]

121. Costa, L.J.; Derman, B.A.; Bal, S.; Sidana, S.; Chhabra, S.; Silbermann, R.; Ye, J.C.; Cook, G.; Cornell, R.F.; Holstein, S.A.; et al. International harmonization in performing and reporting minimal residual disease assessment in multiple myeloma trials. Leukemia 2021, 35, 18-30. [CrossRef]

122. Jasielec, J.K.; Kubicki, T.; Raje, N.; Vij, R.; Reece, D.; Berdeja, J.; Derman, B.A.; Rosenbaum, C.A.; Richardson, P.; Gurbuxani, S.; et al. Carfilzomib, lenalidomide, and dexamethasone plus transplant in newly diagnosed multiple myeloma. Blood 2020, 136, 2513-2523. [CrossRef] [PubMed]

123. Offidani, M.; Corvatta, L.; Gentili, S. Triplet vs. doublet drug regimens for managing multiple myeloma. Expert Opin. Pharmacother. 2018, 19, 137-149. [CrossRef] [PubMed] 
124. Gay, F.; Musto, P.; Scalabrini, D.R.; Galli, M.; Belotti, A.; Zamagni, E.; Bertamini, L.; Zambell, R.; Quaresima, M.; De Sabbata, G.; et al. Survival Analysis of Newly Diagnosed Transplant-Eligible Multiple Myeloma Patients in the Randomized Forte Trial. Blood 2020, 136, 35-37. [CrossRef]

125. Chung, D.J.; Pronschinske, K.B.; Shyer, J.A.; Sharma, S.; Leung, S.; Curran, S.A.; Lesokhin, A.M.; Devlin, S.M.; Giralt, S.A.; Young, J.W. T-cell Exhaustion in Multiple Myeloma Relapse after Autotransplant: Optimal Timing of Immunotherapy. Cancer Immunol. Res. 2016, 4, 61-71. [CrossRef]

126. McCarthy, P.L.; Holstein, S.A.; Petrucci, M.T.; Richardson, P.G.; Hulin, C.; Tosi, P.; Bringhen, S.; Musto, P.; Anderson, K.C.; Caillot, D.; et al. Lenalidomide Maintenance After Autologous Stem-Cell Transplantation in Newly Diagnosed Multiple Myeloma: A Meta-Analysis. J. Clin. Oncol. 2017, 35, 3279-3289. [CrossRef]

127. Jackson, G.H.; Davies, F.E.; Pawlyn, C.; Cairns, D.A.; Striha, A.; Collett, C.; Hockaday, A.; Jones, J.R.; Kishore, B.; Garg, M.; et al. Lenalidomide maintenance versus observation for patients with newly diagnosed multiple myeloma (Myeloma XI): A multicentre, open-label, randomised, phase 3 trial. Lancet Oncol. 2019, 20, 57-73. [CrossRef]

128. Patel, D.A.; Gopalakrishnan, R.; Engelhardt, B.G.; McArthur, E.; Sengsayadeth, S.; Culos, K.A.; Byrne, M.; Goodman, S.; Savani, B.N.; Chinratanalab, W.; et al. Minimal residual disease negativity and lenalidomide maintenance therapy are associated with superior survival outcomes in multiple myeloma. Bone Marrow Transplant. 2020, 55, 1137-1146. [CrossRef]

129. Dimopoulos, M.A.; Gay, F.; Schjesvold, F.; Beksac, M.; Hajek, R.; Weisel, K.C.; Goldschmidt, H.; Maisnar, V.; Moreau, P.; Min, C.K.; et al. Oral ixazomib maintenance following autologous stem cell transplantation (TOURMALINE-MM3): A doubleblind, randomised, placebo-controlled phase 3 trial. Lancet 2019, 393, 253-264. [CrossRef]

130. Salwender, H.; Bertsch, U.; Weisel, K.; Duerig, J.; Kunz, C.; Benner, A.; Blau, I.W.; Raab, M.S.; Hillengass, J.; Hose, D.; et al. Rationale and design of the German-speaking myeloma multicenter group (GMMG) trial HD6: A randomized phase III trial on the effect of elotuzumab in VRD induction/consolidation and lenalidomide maintenance in patients with newly diagnosed myeloma. BMC Cancer 2019, 19, 504. [CrossRef]

131. Moreau, P.; Sonneveld, P.; for the CASSIOPEIA Study Investigators. Daratumumab Maintenance vs Observation in Patients with Newly Diagnosed Multiple Myeloma Treated with Bortezomib, Thalidomide, and Dexamethasone \pm Daratumumab and ASCT: CASSIOPEIA Part 2 Results. J. Clin. Oncol. 2021, 39, 8004. [CrossRef]

132. Costa, L.J.; Chhabra, S.; Godby, K.; Medvedova, E.; Cornell, R.; Hall, A.; Dhakal, B.; Giri, S.; Bal, S.; Silbermann, R.; et al. Daratumumab, carfilzomib, lenalidomide and dexamethasone (Dara-KRd), autologous transplantation and MRD responseadapted treatment duration and cessation in newly diagnosed multiple myeloma. In Proceedings of the EHA Annual Meeting, Virtual Meeting, 12 June 2020; p. E928.

133. Arana, P.; Paiva, B.; Cedena, M.T.; Puig, N.; Cordon, L.; Vidriales, M.B.; Gutierrez, N.C.; Chiodi, F.; Burgos, L.; Anglada, L.L.; et al. Prognostic value of antigen expression in multiple myeloma: A PETHEMA/GEM study on 1265 patients enrolled in four consecutive clinical trials. Leukemia 2018, 32, 971-978. [CrossRef]

134. Paiva, B.; Corchete, L.A.; Vidriales, M.B.; Puig, N.; Maiso, P.; Rodriguez, I.; Alignani, D.; Burgos, L.; Sanchez, M.L.; Barcena, P.; et al. Phenotypic and genomic analysis of multiple myeloma minimal residual disease tumor cells: A new model to understand chemoresistance. Blood 2016, 127, 1896-1906. [CrossRef]

135. Meads, M.B.; Gatenby, R.A.; Dalton, W.S. Environment-mediated drug resistance: A major contributor to minimal residual disease. Nat. Rev. Cancer. 2009, 9, 665-674. [CrossRef]

136. Kortüm, K.M.; Mai, E.K.; Hanafiah, N.H.; Shi, C.X.; Zhu, Y.X.; Bruins, L.; Barrio, S.; Jedlowski, P.; Merz, M.; Xu, J.; et al. Targeted sequencing of refractory myeloma reveals a high incidence of mutations in CRBN and Ras pathway genes. Blood 2016, 128, 1226-1233. [CrossRef] [PubMed]

137. Barrio, S.; Munawar, U.; Zhu, Y.X.; Giesen, N.; Shi, C.X.; Da Via, M.; Sanchez, R.; Bruins, L.; Demler, T.; Muller, N.; et al. IKZF1/3 and CRL4-CRBN E3 ubiquitin ligase mutations and IMiD resistance in multiple myeloma. Haematologica 2020, 105, e237-e241. [CrossRef]

138. Franssen, L.E.; Nijhof, I.S.; Couto, S.; Levin, M.D.; Bos, G.M.J.; Broijl, A.; Klein, S.K.; Ren, Y.; Wang, M.; Koene, H.R.; et al. Cereblon loss and up-regulation of c-Myc are associated with lenalidomide resistance in multiple myeloma patients. Haematologica 2018, 103, e368-e371. [CrossRef] [PubMed]

139. Zhu, Y.X.; Braggio, E.; Shi, C.-X.; Bruins, L.A.; Schmidt, J.E.; Van Wier, S.; Chang, X.-B.; Bjorklund, C.C.; Fonseca, R.; Bergsagel, P.L.; et al. Cereblon expression is required for the antimyeloma activity of lenalidomide and pomalidomide. Blood 2011, 118, 4771-4779. [CrossRef] [PubMed]

140. Di Bacco, A.; Bahlis, N.J.; Munshi, N.C.; Avet-Loiseau, H.; Masszi, T.; Viterbo, L.; Pour, L.; Ganly, P.; Cavo, M.; Langer, C.; et al. c-MYC expression and maturity phenotypes are associated with outcome benefit from addition of ixazomib to lenalidomidedexamethasone in myeloma. Eur. J. Haematol. 2020, 105, 35-46. [CrossRef] [PubMed]

141. Nawrocki, S.T.; Carew, J.S.; Maclean, K.H.; Courage, J.F.; Huang, P.; Houghton, J.A.; Cleveland, J.L.; Giles, F.J.; McConkey, D.J. Myc regulates aggresome formation, the induction of Noxa, and apoptosis in response to the combination of bortezomib and SAHA. Blood 2008, 112, 2917-2926. [CrossRef]

142. Orlowski, R.Z.; Eswara, J.R.; Lafond-Walker, A.; Grever, M.R.; Orlowski, M.; Dang, C.V. Tumor growth inhibition induced in a murine model of human Burkitt's lymphoma by a proteasome inhibitor. Cancer Res. 1998, 58, 4342-4348. [PubMed] 
143. Barrio, S.; Stühmer, T.; Da-Viá, M.; Barrio-Garcia, C.; Lehners, N.; Besse, A.; Cuenca, I.; Garitano-Trojaola, A.; Fink, S.; Leich, E.; et al. Spectrum and functional validation of PSMB5 mutations in multiple myeloma. Leukemia 2019, 33, 447-456. [CrossRef] [PubMed]

144. Bolli, N.; Genuardi, E.; Ziccheddu, B.; Martello, M.; Oliva, S.; Terragna, C. Next-Generation Sequencing for Clinical Management of Multiple Myeloma: Ready for Prime Time? Front. Oncol. 2020, 10, 189. [CrossRef] [PubMed]

145. Franssen, L.E.; Stege, C.A.M.; Zweegman, S.; van de Donk, N.W.C.J.; Nijhof, I.S. Resistance Mechanisms towards CD38-Directed Antibody Therapy in Multiple Myeloma. J. Clin. Med. 2020, 9, 1195. [CrossRef] [PubMed]

146. Nijhof, I.S.; Casneuf, T.; van Velzen, J.; van Kessel, B.; Axel, A.E.; Syed, K.; Groen, R.W.; van Duin, M.; Sonneveld, P.; Minnema, M.C.; et al. CD38 expression and complement inhibitors affect response and resistance to daratumumab therapy in myeloma. Blood 2016, 128, 959-970. [CrossRef]

147. Mikhael, J.; Belhadj-Merzoug, K.; Hulin, C.; Vincent, L.; Moreau, P.; Gasparetto, C.; Pour, L.; Spicka, I.; Vij, R.; Zonder, J.; et al. A phase 2 study of isatuximab monotherapy in patients with multiple myeloma who are refractory to daratumumab. Blood Cancer $J$. 2021, 11, 89. [CrossRef]

148. Richardson, P.G.; Perrot, A.; San-Miguel, J.F.; Beksac, M.; Spicka, I.; Leleu, X.; Schjesvold, F.; Moreau, P.; Dimopoulos, M.A.; Huang, J.S.Y.; et al. Updates from ICARIA-MM, a phase 3 study of isatuximab (Isa) plus pomalidomide and low-dose dexamethasone (Pd) versus Pd in relapsed and refractory multiple myeloma (RRMM). J. Clin. Oncol. 2021, 39, 8017. [CrossRef]

149. Giralt, S.; Garderet, L.; Durie, B.; Cook, G.; Gahrton, G.; Bruno, B.; Hari, P.; Lokhorst, H.; McCarthy, P.; Krishnan, A.; et al. American Society of Blood and Marrow Transplantation, European Society of Blood and Marrow Transplantation, Blood and Marrow Transplant Clinical Trials Network, and International Myeloma Working Group Consensus Conference on Salvage Hematopoietic Cell Transplantation in Patients with Relapsed Multiple Myeloma. Biol. Blood Marrow Transplant. 2015, 21, 2039-2051. [CrossRef]

150. Giralt, S.; Costa, L.J.; Maloney, D.; Krishnan, A.; Fei, M.; Antin, J.H.; Brunstein, C.; Geller, N.; Goodman, S.; Hari, P.; et al. Tandem Autologous-Autologous versus Autologous-Allogeneic Hematopoietic Stem Cell Transplant for Patients with Multiple Myeloma: Long-Term Follow-Up Results from the Blood and Marrow Transplant Clinical Trials Network 0102 Trial. Biol. Blood Marrow Transplant. 2020, 26, 798-804. [CrossRef]

151. Costa, L.J.; Iacobelli, S.; Pasquini, M.C.; Modi, R.; Giaccone, L.; Blade, J.; Schonland, S.; Evangelista, A.; Perez-Simon, J.A.; Hari, P.; et al. Long-term survival of $1338 \mathrm{MM}$ patients treated with tandem autologous vs. autologous-allogeneic transplantation. Bone Marrow Transplant. 2020, 55, 1810-1816. [CrossRef]

152. Luoma, S.; Silvennoinen, R.; Rauhala, A.; Niittyvuopio, R.; Martelin, E.; Lindström, V.; Heiskanen, J.; Volin, L.; Ruutu, T.; Nihtinen, A. Long-term outcome after allogeneic stem cell transplantation in multiple myeloma. Ann. Hematol. 2021, 100, 1553-1567. [CrossRef]

153. Paiva, B.; Azpilikueta, A.; Puig, N.; Ocio, E.M.; Sharma, R.; Oyajobi, B.O.; Labiano, S.; San-Segundo, L.; Rodriguez, A.; Aires-Mejia, I.; et al. PD-L1/PD-1 presence in the tumor microenvironment and activity of PD-1 blockade in multiple myeloma. Leukemia 2015, 29, 2110-2113. [CrossRef]

154. Puig, N.; Corchete-Sánchez, L.A.; Pérez-Morán, J.J.; Dávila, J.; Paíno, T.; de la Rubia, J.; Oriol, A.; Martín-Sánchez, J.; de Arriba, F.; Bladé, J.; et al. Pembrolizumab as Consolidation Strategy in Patients with Multiple Myeloma: Results of the GEM-Pembresid Clinical Trial. Cancers 2020, 12, 3615. [CrossRef]

155. D’Souza, A.; Hari, P.; Pasquini, M.; Braun, T.; Johnson, B.; Lundy, S.; Couriel, D.; Hamadani, M.; Magenau, J.; Dhakal, B.; et al. A Phase 2 Study of Pembrolizumab during Lymphodepletion after Autologous Hematopoietic Cell Transplantation for Multiple Myeloma. Biol. Blood Marrow Transplant. 2019, 25, 1492-1497. [CrossRef]

156. Raje, N.; Berdeja, J.; Lin, Y.; Siegel, D.; Jagannath, S.; Madduri, D.; Liedtke, M.; Rosenblatt, J.; Maus, M.V.; Turka, A.; et al. Anti-BCMA CAR T-Cell Therapy bb2121 in Relapsed or Refractory Multiple Myeloma. N. Engl. J. Med. 2019, 380, $1726-1737$. [CrossRef]

157. Munshi, N.C.; Anderson, L.D., Jr.; Shah, N.; Jagannath, S.; Berdeja, J.G.; Lonial, S.; Raje, N.S.; Siegel, D.; Lin, Y.; Oriol, A.; et al. Idecabtagene vicleucel (ide-cel; bb2121), a BCMA-targeted CAR T-cell therapy, in patients with relapsed and refractory multiple myeloma (RRMM): Initial KarMMa results. J. Clin. Oncol. 2020, 38, 8503. [CrossRef]

158. Berdeja, J.G.; Madduri, D.; Usmani, S.Z.; Singh, I.; Zudaire, E.; Yeh, T.M.; Allred, A.J.; Olyslager, Y.; Banerjee, A.; Goldberg, J.D.; et al. Update of CARTITUDE-1: A phase Ib/II study of JNJ-4528, a B-cell maturation antigen (BCMA)-directed CAR-T-cell therapy, in relapsed/refractory multiple myeloma. J. Clin. Oncol. 2020, 38, 8505. [CrossRef]

159. Cho, S.F.; Anderson, K.C.; Tai, Y.T. Targeting B Cell Maturation Antigen (BCMA) in Multiple Myeloma: Potential Uses of BCMA-Based Immunotherapy. Front. Immunol. 2018, 9, 1821. [CrossRef]

160. Cohen, A.D.; Garfall, A.L.; Stadtmauer, E.A.; Melenhorst, J.J.; Lacey, S.F.; Lancaster, E.; Vogl, D.T.; Weiss, B.M.; Dengel, K.; Nelson, A.; et al. B cell maturation antigen-specific CAR T cells are clinically active in multiple myeloma. J. Clin. Investig. 2019, 129, 2210-2221. [CrossRef] [PubMed]

161. Gattinoni, L.; Lugli, E.; Ji, Y.; Pos, Z.; Paulos, C.M.; Quigley, M.F.; Almeida, J.R.; Gostick, E.; Yu, Z.; Carpenito, C.; et al. A human memory T cell subset with stem cell-like properties. Nat. Med. 2011, 17, 1290-1297. [CrossRef] [PubMed]

162. Dancy, E.; Garfall, A.L.; Cohen, A.D.; Fraietta, J.A.; Davis, M.; Levine, B.L.; Siegel, D.L.; Stadmauer, E.A.; Vogl, D.T.; Waxman, A.; et al. Clinical predictors of T cell fitness for CAR T cell manufacturing and efficacy in multiple myeloma. Blood 2018, 132, 1886. [CrossRef] 
163. Zanwar, S.; Nandakumar, B.; Kumar, S. Immune-based therapies in the management of multiple myeloma. Blood Cancer J. 2020, 10, 84. [CrossRef] [PubMed]

164. Timmers, M.; Roex, G.; Wang, Y.; Campillo-Davo, D.; Van Tendeloo, V.F.I.; Chu, Y.; Berneman, Z.N.; Luo, F.; Van Acker, H.H.; Anguille, S. Chimeric Antigen Receptor-Modified T Cell Therapy in Multiple Myeloma: Beyond B Cell Maturation Antigen. Front. Immunol. 2019, 10, 1613. [CrossRef] [PubMed]

165. Gagelmann, N.; Riecken, K.; Wolschke, C.; Berger, C.; Ayuk, F.A.; Fehse, B.; Kröger, N. Development of CAR-T cell therapies for multiple myeloma. Leukemia 2020, 34, 2317-2332. [CrossRef] [PubMed]

166. Works, M.; Soni, N.; Hauskins, C.; Sierra, C.; Baturevych, A.; Jones, J.C.; Curtis, W.; Carlson, P.; Johnstone, T.G.; Kugler, D.; et al. Anti-B-cell Maturation Antigen Chimeric Antigen Receptor T cell Function against Multiple Myeloma Is Enhanced in the Presence of Lenalidomide. Mol. Cancer Ther. 2019, 18, 2246-2257. [CrossRef] [PubMed]

167. Yan, Z.; Cao, J.; Cheng, H.; Qiao, J.; Zhang, H.; Wang, Y.; Shi, M.; Lan, J.; Fei, X.; Jin, L.; et al. A combination of humanised anti-CD19 and anti-BCMA CAR T cells in patients with relapsed or refractory multiple myeloma: A single-arm, phase 2 trial. Lancet Haematol. 2019, 6, e521-e529. [CrossRef]

168. Foglietta, M.; Castella, B.; Mariani, S.; Coscia, M.; Godio, L.; Ferracini, R.; Ruggeri, M.; Muccio, V.; Omedé, P.; Palumbo, A.; et al. The bone marrow of myeloma patients is steadily inhabited by a normal-sized pool of functional regulatory T cells irrespectiveof the disease status. Haematologica 2014, 99, 1605-1610. [CrossRef]

169. Marsh-Wakefield, F.; Kruzins, A.; McGuire, H.M.; Yang, S.; Bryant, C.; Fazekas de St Groth, B.; Nassif, N.; Byrne, S.N.; Gibson, J.; Brown, C.; et al. Mass Cytometry Discovers Two Discrete Subsets of CD39- Treg Which Discriminate MGUS From Multiple Myeloma. Front. Immunol. 2019, 10, 1596. [CrossRef]

170. Bhutani, M.; Foureau, D.; Zhang, Q.; Robinson, M.; Wynn, A.S.; Steuerwald, N.M.; Druhan, L.J.; Guo, F.; Rigby, K.; Turner, M.; et al. Peripheral immunotype correlates with minimal residual disease status and is modulated by Immunomodulatory drugs in multiple myeloma. Biol. Blood Marrow Transplant. 2019, 25, 459-465. [CrossRef]

171. Suzuki, K.; Nishiwaki, K.; Yano, S. Treatment Strategies Considering Micro-Environment and Clonal Evolution in Multiple Myeloma. Cancers 2021, 13, 215. [CrossRef]

172. Kostopoulos, I.V.; Ntanasis-Stathopoulos, I.; Gavriatopoulou, M.; Tsitsilonis, O.E.; Terpos, E. Minimal Residual Disease in Multiple Myeloma: Current Landscape and Future Applications With Immunotherapeutic Approaches. Front. Oncol. 2020, 10, 860. [CrossRef] [PubMed]

173. Romano, A.; Laura Parrinello, N.; Cerchione, C.; Letizia Consoli, M.; Parisi, M.; Calafiore, V.; Martino, E.; Conticello, C.; Di Raimondo, F.; Alberto Palumbo, G. The NLR and LMR ratio in newly diagnosed MM patients treated upfront with novel agents. Blood Cancer J. 2017, 7, 649. [CrossRef] [PubMed]

174. Dosani, T.; Covut, F.; Beck, R.; Driscoll, J.J.; de Lima, M.; Malek, E. Significance of the absolute lymphocyte/monocyte ratio as a prognostic immune biomarker in newly diagnosed multiple myeloma. Blood Cancer J. 2017, 7, e579. [CrossRef] [PubMed]

175. Shi, L.; Qin, X.; Wang, H.; Xia, Y.; Li, Y.; Chen, X.; Shang, L.; Tai, Y.T.; Feng, X.; Acharya, P.; et al. Elevated neutrophilto-lymphocyte ratio and monocyte-to-lymphocyte ratio and decreased platelet-to-lymphocyte ratio are associated with poor prognosis in multiple myeloma. Oncotarget 2017, 8, 18792-18801. [CrossRef] [PubMed]

176. Suzuki, K.; Nishiwaki, K.; Nagao, R.; Katori, M.; Fukushima, R.; Hattori, D.; Masuoka, H.; Yano, S. Clinical significance of the lymphocyte-to-monocyte ratio in multiple myeloma patients with negative minimal residual disease: A single-center retrospective analysis. Int. J. Hematol. 2021. [CrossRef] [PubMed] 